\title{
PHYSICO-CHEMICAL CHARACTERISTICS OF TIN MINING POND WATER USED FOR IRRIGATION IN PLATEAU STATE, CENTRAL NIGERIA
}

\author{
${ }^{* 1}$ Mafuyai, G. M., ${ }^{2}$ Ayuba, M. S. and ${ }^{3}$ Zang, C. U.
}

\author{
${ }^{*}$ Department of Chemistry University of Jos, Jos Nigeria \\ ${ }^{2,3}$ Department of Science Laboratory Technology University of Jos, Jos Nigeria \\ "Corresponding Author Email: godwinmaf@gmail.com
}

\begin{abstract}
The present work was conducted by monitoring the water from twelve major tin mine ponds water in Plateau State, North Central Nigeria (Bokkos, Barkin - Ladi and Jos - South) used for irrigation. The quality was assessed in terms of physico-chemical parameters for dry and rainy seasons. Their physico-chemical parameters such as; Turbidity, pH, Temperature, Electrical Conductivity (EC), Cation Exchange Capacity (CEC), Total Dissolved Solids (TDS), Total Suspended Solids (TSS), Total alkalinity (TA), Total Hardness (TH), Dissolved Oxygen (DO), Chemical Oxygen Demand (COD), Biological Oxygen Demand (BOD), Phosphate ( $\left.\mathrm{PO}_{4}{ }^{3-}\right)$, Sulphate $\left(\mathrm{SO}_{4}{ }^{2-}\right)$, $\mathrm{Chloride}^{-\mathrm{Cl}^{-}}$ ), Fluoride $\left(\mathrm{F}^{-}\right)$, Sodium $\left(\mathrm{Na}^{+}\right)$and Potassium $\left(\mathrm{K}^{+}\right)$were investigated to ascertain the water quality for irrigation purposes. Water quality parameters with regards to its use for the purpose of irrigation such as FAO/WHO/FEPA standards satisfy the requirement for use in agriculture. However, turbidity which ranged from18.1 - 27.4 and $15.9-18.8$, dissolved oxygen $20.9-26.3$ and $20.2-27.4 \mathrm{mg} / \mathrm{L}$, Total alkalinity $101-134$ and $122-167 \mathrm{mg} / \mathrm{L}$, total phosphate $6.3-8.9$ and $6.5-10.5 \mathrm{mg} / \mathrm{L}$, BOD $7.4-23.8$ and $7.2-29.2 \mathrm{mg} / \mathrm{L}$, potassium $1.13-1.18$ and $3.81-4.63 \mathrm{mg} / \mathrm{L}$ both in dry and rainy seasons, respectively were found to be above the irrigation water standard limits. The study therefore recommends that the mining pond water should be used with caution as some of the parameters are liable to be toxic to the irrigated crops. The positive correlation exhibited among some of the parameters examined is a clear indication of a common relationship between these sources of water.
\end{abstract}

Keywords: contamination, irrigation, mining, ponds, Tin

LICENSE: This work by Open Journals Nigeria is licensed and published under the Creative Commons Attribution License 4.0 International License, which permits unrestricted use, distribution, and reproduction in any medium, provided this article is duly cited.

COPYRIGHT: The Author(s) completely retain the copyright of this published article.

OPEN ACCESS: The Author(s) approves that this article remains permanently online in the open access (OA) mode.

QA: This Article is published in line with "COPE (Committee on Publication Ethics) and PIE (Publication Integrity \& Ethics)". 


\section{INTRODUCTION}

Water demand is remarkably increasing in many countries around the world for various reasons due to population expansion, economy's prosperity, and the improvement of living standards. One of the most demanding fields, however, is agriculture, since it makes use of $67 \%$ of total water withdrawal which represents $86 \%$ of water consumption in 2000 as reported (UNEP 2005). According to the Food and Agriculture Organization, 277 million hectares of lands are irrigated out of 1.4 billion hectares of arable ones, which provides one-third of the world's food production (Gurel $e t$ al., 2007).

Irrigation with tin mining pond water provides an economic and cost-effective option for the scarcity of water in central part of Nigeria. Rapid population growth, increased urbanization, and a rising demand for drinking and irrigation water coupled with tightening regulatory restrictions on disposal of wastewater, all take the lead with discovery of Tin in 1903 and 1904 during the colonial era in which large mining ponds were dug in 1938 increasing use of tin mine pond water for irrigation in Plateau State (Mafuyai et al., 2019a). The quality of irrigation water is a crucial factor for long term soil productivity. Poor quality water in conjunction with other inorganic/organic fertilizers for a long time in irrigation can make the soil less productive or even barren depending on the amount and type of substances present in the water (Bixio et al., 2006). Many areas in Nigeria are facing a serious problem on both scarcity and quality of water (Gongden and Lohdip, 2015). The deterioration of water quality is associated with climate change and population growth. Hence, the quality of surface water is not only dependent on natural environmental processes such as weathering, erosion and precipitation, but also on the influence of anthropogenic activities including urbanization, agricultural activities and mining (Khatri and Tyagi, 2015).

Tin was first recognized in Nigeria in the early 1900s and dominated most of the production for over half a century. The expatriate exploration with drag line began in 1904 in Plateau State (Samuel et al., 2015). The production of tin in Jos Plateau started with 1.5 metric tons in 1914 and reached peak production of 17.740 metric tons in 1943 when Nigeria became the $6^{\text {th }}$ world producer (Patterson, 1986). However, the lack of proper environmental monitoring and enforcement during mining operations resulted to environmental degradation. This led to the creation of 10-40meter-deep mine ponds filled with accumulated water (Balamurugan, 1991). The early tin mines were concentrated in North-Central Nigeria and consequently became one of the largest tin producers in Nigeria. The abundant ex-mining ponds in the early 1980s in with other local miners using hand dug wells in central Nigeria with large volumes of water have been suggested to support the daily water demand of the inhabitants of the areas (Low et al., 2016; Koki et al., 2017).

Various studies have been carried out to show the physico-chemical characteristics of wastewater which has direct and indirect impact on soil health and also the mobility of heavy metals from soil to vegetation. Some salient works in these aspects have been highlighted. Alghobar and Suresh, (2017) conducted a study on irrigation water sources (mines water, sewage water, treated sewage water, mixed water and ground water) and considered the following parameters; temperature, $\mathrm{pH}, \mathrm{EC}, \mathrm{BOD}, \mathrm{COD}$, TDS, $\mathrm{Ca}^{2+}, \mathrm{Na}^{+}, \mathrm{K}^{+}, \mathrm{Cl}^{-}, \mathrm{PO}_{4}{ }^{3-}$ and $\mathrm{SO}_{4}{ }^{2-}$ concentration. Roli (2014) analyzed sewage water used in the irrigation of suburb of Jamkhandi, Karnataka revealed that good amount of $\mathrm{Zn}, \mathrm{Cu}$ and $\mathrm{Mn}$ enrichment in irrigation water and soil. The physico-chemical characteristics (pH, TDS,

$\mathrm{Cl}^{-}$alkalinity, total hardness, $\mathrm{COD}, \mathrm{NO}_{3}{ }^{-}$and $\mathrm{PO}_{4}{ }^{3-}$ ) of Ayad river wastewater used for irrigation were suitable 
(Bamniya et al., 2010). The analyzed characteristics of wastewater used in the irrigation of agricultural fields of Durgapur (Gupta et al., 2008). Parameters such as pH, EC, TSS, TDS, total hardness, $\mathrm{Cl}-, \mathrm{NO}_{3}{ }^{-}, \mathrm{PO}_{4}{ }^{3-}, \mathrm{SO}_{4}{ }^{2-}, \mathrm{COD}$ and total Fe content in the irrigation water were considered. The comparative physico-chemical properties of drinking water and treated wastewater used for irrigation (Manas et al., 2009) considered the following parameters; COD, $\mathrm{BOD}_{5}, \mathrm{TSS}, \mathrm{pH}, \mathrm{EC}, \mathrm{TP}, \mathrm{NO}_{3}{ }^{-}, \mathrm{SO}_{4}{ }^{2-}, \mathrm{Cl}^{-}, \mathrm{Ca}^{2+}, \mathrm{K}^{+}$. Physico-chemical characteristics of irrigation water used in Dinapur and Lohta sites located in suburban areas of Varanasi was identified to be suitable for irrigation with close monitoring (Singh et al., 2009). Physico-chemical characteristics of raw effluent and open cast pit (OCP) water used for irrigation (Gupta et al., 2010) and the physicochemical properties of the soil samples from study area, Bestari Jaya, Kuala Selangor, Peninsular Malaysia were analyzed (Muhammad et al., 2010).

There is a global concern on the quality of surface water for consideration as source of supply for agricultural purpose, human consumption and other domestic needs (Kazi et al., 2009). The environmental status of tin mined ponds is dependent on the type of the pond and its exposure to various environmental factors. The shortage of water for daily human and domestic activities especially in the period of dry season has prompted the search for other sources of water supply. Based on the water crisis faced by local farmers to enhance their crop production in Plateau State, holistic approach is needed to address it decisively. It is therefore, imperative to determine the physico-chemical parameters of the mining pond water to ascertain their suitability for irrigation purpose.

\section{MATERIALS AND METHODS \\ STUDY AREA}

The study areas lie between latitude $9^{\circ} 18^{\prime} \mathrm{N}$ to $9^{\circ} 54^{\prime} \mathrm{N}$ and longitude $8^{\circ} 50^{\prime} \mathrm{E}$ to $8^{\circ} 59^{\prime} \mathrm{E}$ and this cover an area of about $3224 \mathrm{~km}^{2}$ in terms of land mass. According to National Population Commission (NPC, 2006), the studied area has an estimated population of 671,157 . The study area is a hosts to a lot of mining activities by foreign companies such

British Mines Corporation Limited, Bisichi Jenta Limited, Gold and Base Corporation, Exland and Kaduna Prospectors (Kazi et al., 2009). The map of the studied Local Government Areas; Jos - South, Barkin- Ladi and Bokkos as shown in (Figure 1a, b and c) with the sampling ponds labeled. 


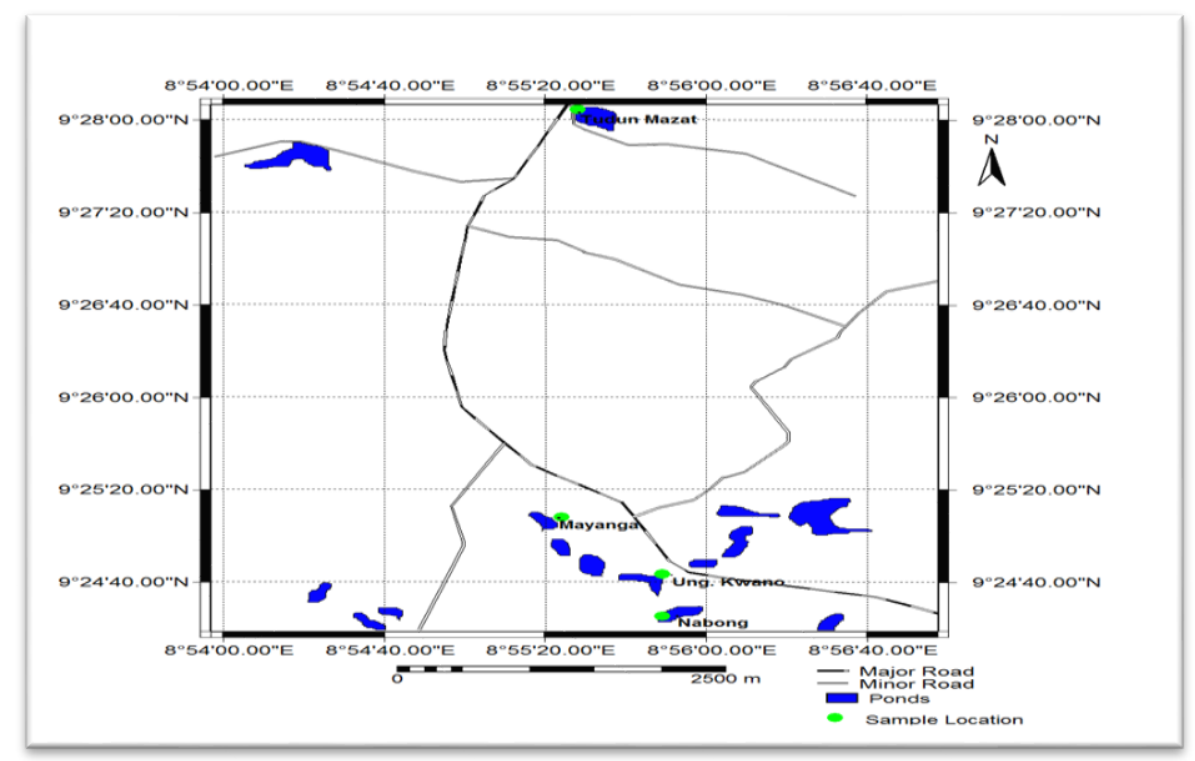

Figure 1a: Map of Jos - South showing sampling ponds

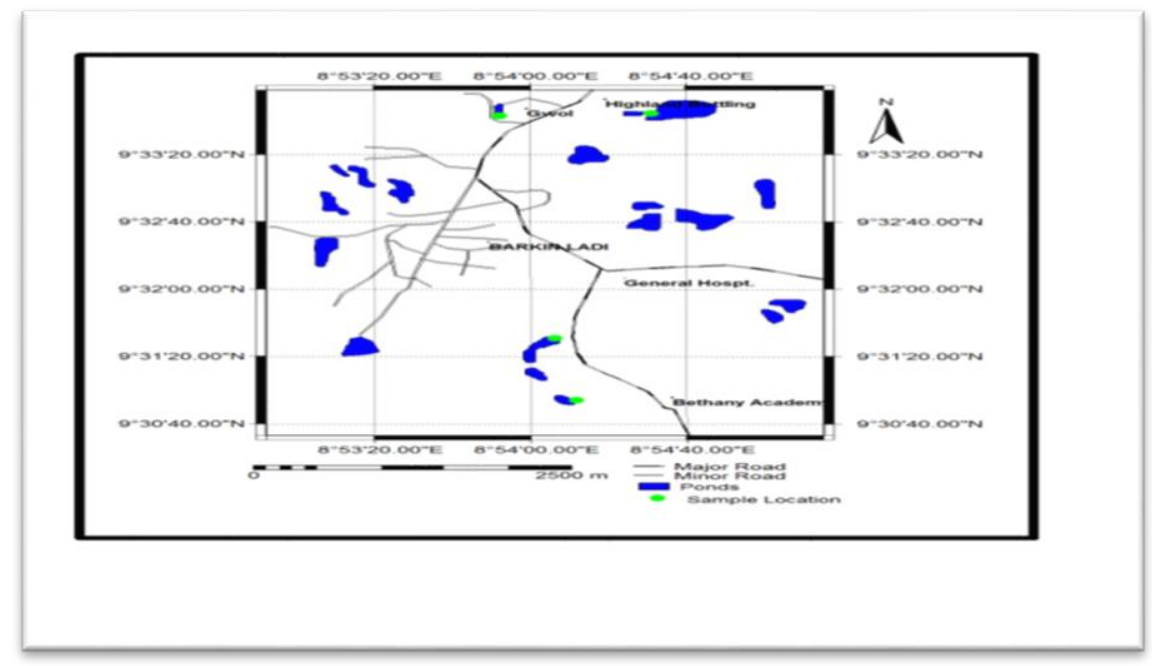

Figure 1b: Map of Barkin - Ladi showing sampling ponds 


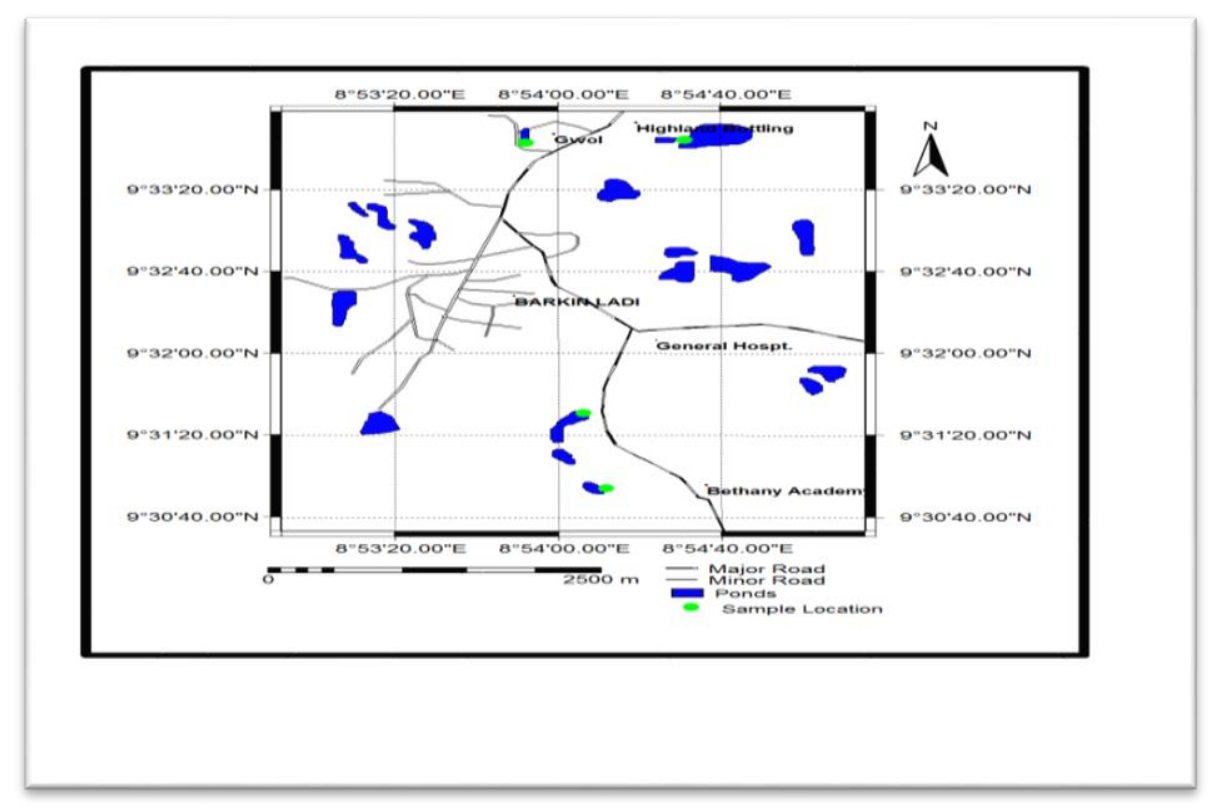

Figure 1c: Map of Bokkos showing sampling ponds

These companies rendered the areas derelict with numerous waste dumps and ponds. The impact of the past mining activities on the landscape is devastating as several tin mined-out pits ranging from $10 \mathrm{~m}$ to about $40 \mathrm{~m}$ in depth were left with various hazardous effects (Figure 2a, b). These tin mined-out pits which are filled with water are generally referred to as Mine Ponds Water (Figure 3a, b, c). The people of these areas are predominantly farmers and use the mine ponds to irrigate crops such; potatoes, tomato, pepper, cabbage, carrot, spinach, garden egg and many other varieties of crops (Mafuyai et al., 2020).

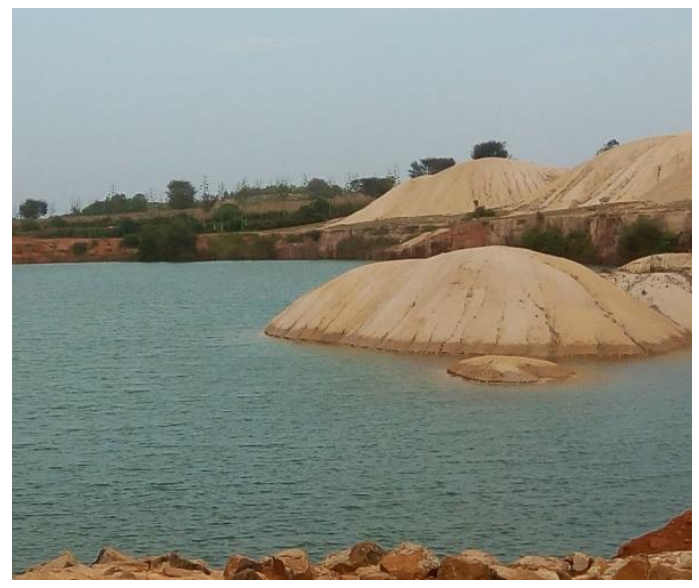

(a)

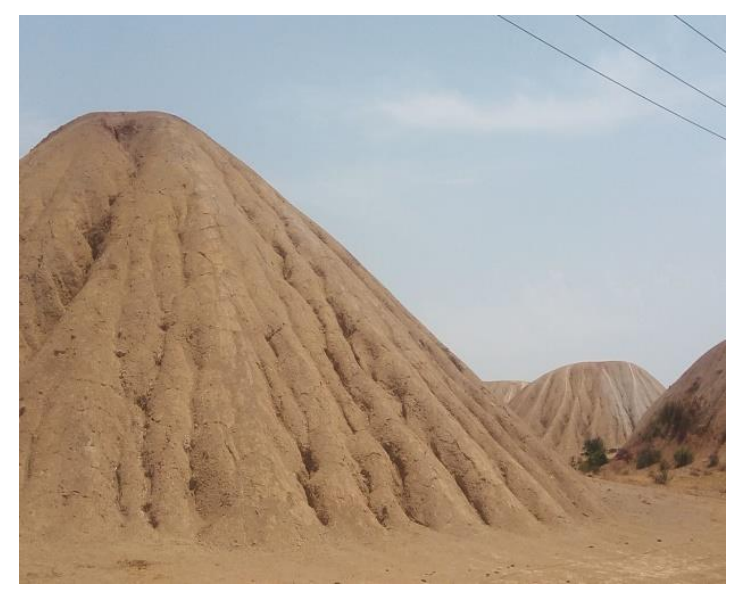

(b)

Figure 2: Some derelict areas (a) deep pond (b) mined dump (Cutesy G. M. Mafuyai, 2020) 


\section{SAMPLING AND PRESERVATION}

The samples of water were collected from the study areas using standard analytical methods (APHA, 1998; FAO,1985). A total of twelve (12) major tin mining ponds, four (4) from each Local Government Areas studied and Global Position System (GPS) of each sampling station documented. At each sampling point, the pitcher was lowered completely into the water at about $20 \mathrm{~cm}$ to obtain desired volume; samples were immediately placed in ice boxes after taking the temperature and $\mathrm{pH}$ and transported to the laboratory for analysis. In each of the pond four areas were located and the sampling done in triplicate from each of the site identified in the pond. The same sampling points were used and 1L of water was collected from both the identified sites in wet and dry seasons from the mining ponds, totaling 96 samples in the two seasons.

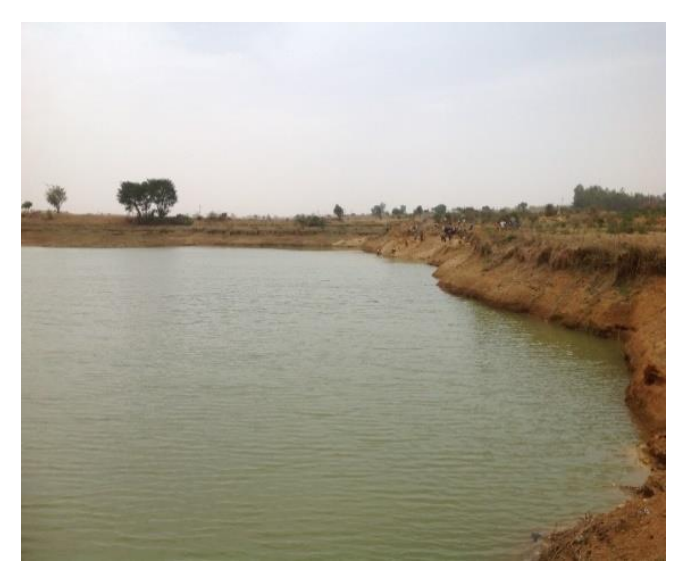

(a)

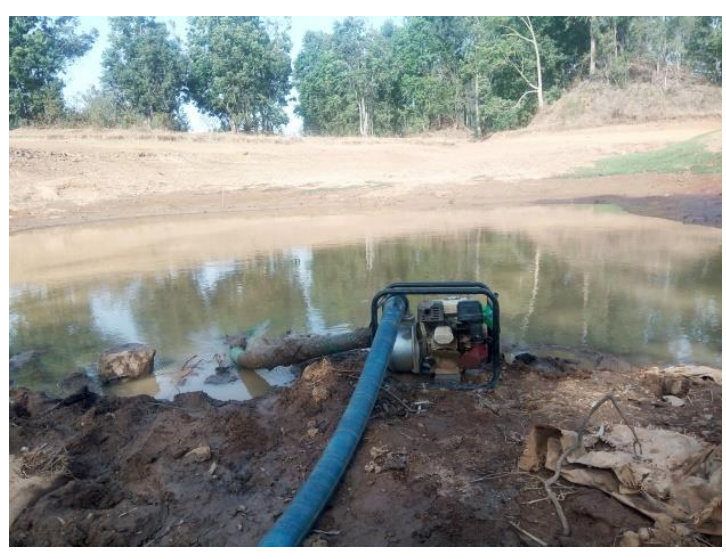

(b)

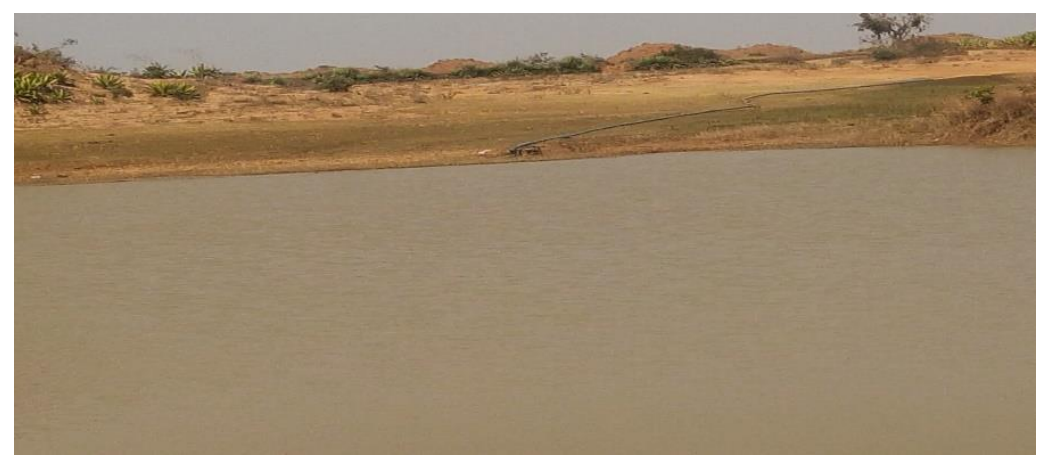

(c)

Figure 3: Tin mining pond used for irrigation in (a) Bokkos, (b) Barkin-Ladi (c) Jos- South. (Cutesy G. M. Mafuyai, 2020)

The water samples were obtained in 2018 and 2019 during the dry seasons (March) and rainy seasons (August) from each of the ponds and analyzed for water quality parameters (temperature, turbidity, $\mathrm{pH}$, electrical conductivity, total 
alkalinity, TDS, TSS, COD, BOD, DO, $\mathrm{PO}_{4}{ }^{3-}, \mathrm{SO}_{4}{ }^{2-}, \mathrm{Cl}^{-}, \mathrm{Na}^{+}, \mathrm{K}^{+}$) using standard methods of examination of water as shown in the table below.

Table 1: Summary of Analytical Procedures used for the Analysis

\begin{tabular}{|c|c|c|}
\hline Parameters & Procedure & Reference \\
\hline Turbidity & Nephelometer & APHA 1998 \\
\hline Temperature & Thermometer & APHA 1999 \\
\hline $\mathrm{pH}$ & pH Meter & APHA 2000 \\
\hline EC & Conductivity meter & Saxena 1998 \\
\hline TSS & weight difference using Drying Oven & APHA 2002 \\
\hline TDS & weight difference using Drying Oven & APHA 2003 \\
\hline $\mathrm{BOD}$ & Titrimetry & APHA 2004 \\
\hline $\mathrm{COD}$ & Titrimetry & APHA 2005 \\
\hline DO & Titrimetry & APHA 2006 \\
\hline TA & Titrimetry & Saxena 1998 \\
\hline $\mathrm{TH}$ & Titrimetry & APHA 2008 \\
\hline $\mathrm{Cl}^{-}$ & Titrimetry & APHA 2009 \\
\hline $\mathrm{NO}_{3}{ }^{-}$ & Spectrophotometry & APHA 2010 \\
\hline $\mathrm{SO}_{4}{ }^{2-}$ & Spectrophotometry & APHA 2011 \\
\hline $\mathrm{TPO}_{4}{ }^{3-}$ & Spectrophotometry & APHA 2012 \\
\hline $\mathrm{F}^{-}$ & Ion selective electrode & APHA 2013 \\
\hline $\mathrm{NH}_{4}^{+}$ & Spectrophotometry & APHA 2014 \\
\hline $\mathrm{Na}^{+}$ & flame photometry & Black 1965 \\
\hline $\mathrm{K}^{+}$ & flame photometry. & Black 1965 \\
\hline
\end{tabular}

\section{CONTROL AND QUALITY ASSURANCE}

Analytical grade reagents and distilled deionized water were used throughout the study. Precision and accuracy of analyses was ensured through replicate analyses by carrying experiment on each of sample three times using standard analytical procedures.

\section{KARL PEARSON'S COEFFICIENT OF CORRELATION}

Coefficient of correlation ( $r$ ) is a quantitative measure of the correlation between two variables. The correlation coefficient measure correlation based on arithmetic mean and standard deviation. This method can be used to measure correlation for individual series as well as for grouped data.

$$
r=\sum \frac{(\bar{X}-X)(\bar{Y}-Y)}{n S x S y}
$$


where, $r=$ coefficient of correlation, $X=$ variable $X, \bar{X}=$ mean of variable $X, Y=$ variable $Y, \bar{Y}=$ mean of variable $\mathrm{Y}, \mathrm{n}=$ number of pairs of variables, $\mathrm{S} x=\mathrm{SD}$ of variable $\mathrm{X}$, and $\mathrm{S} y=\mathrm{SD}$ of variable $\mathrm{Y}$.

Statistical analysis of data was carried out using Microsoft Office Excel 2010 and the SPSS 16.0 statistical package programs.

\section{STUDENT T - TEST}

This test was used for testing the significance of difference between the means of two different samples of small size. It can be calculated using the following formula:

$$
\mathrm{t}=\sqrt[\mathrm{d}]{\mathrm{SDd}}
$$

where, $\bar{d}=$ the mean of the difference between the paired values, SDd = standard deviation of the difference.

\section{RESULTS AND DISCUSSION RESULTS}

The mean and standard deviation of the results of physico-chemical parameters for Bokkos, Barkin - Ladi and Jos South Plateau Central Nigeria, are all presented in Tables 2, respectively. The FAO/WHO standards are also presented along with the physico-chemical parameters. The Pearson's correlation coefficient matrix between the parameters that were determined in both seasons in each study area are presented in Tables 3, 4, 5, 6, 7, 8,). The mean turbidity of the mining pond water in dry and rainy seasons ranged from $18.1-27.4$ and $15.9-18.8 \mathrm{NTU}$, respectively. In this study, the turbidity in dry season were highest in Barkin - Ladi 27.4 \pm 1.2 with the lowest in the rainy season in Bokkos $15.9 \pm 0.6$. The high turbidity in dry season is connected with wind action during the period blows a lot of debris into the ponds due to inadequate soil cover, these result in low oxygen and sunlight penetration for aquatic species. The mean temperature of the mining pond water in dry and rainy seasons ranged between $23.8-25.1^{\circ} \mathrm{C}$ and $28.5-29.3$ ${ }^{0} \mathrm{C}$, respectively. The highest temperature in dry and rainy seasons was in Jos - South $25.1{ }^{\circ} \mathrm{C}$ and $29.3{ }^{\circ} \mathrm{C}$ respectively.

The mean $\mathrm{pH}$ of the mining pond water used in irrigation ranged from $6.38-6.73$ during dry season, while that of rainy season was slightly higher than that of dry season, with a range of $6.4-6.8$. The mean $\mathrm{pH}$ values recorded in all sampling sites were within the FAO/WHO, (2007) permissible limits of $6.5-8.5$. The mean electrical conductivity (EC) values of mining pond water in the study sites range from $109-220 \mu \mathrm{S} \mathrm{cm}^{-1}$ in dry season, while in rainy season the range were $123-128 \mu \mathrm{Scm}^{-1}$. The mean concentration of TSS in the tin mining pond water used in irrigation of vegetables in dry - and - rainy season were in range of $520-718$ and $10.4-123 \mathrm{mg} / \mathrm{L}$, respectively.

The mean values of BOD in the tin mine pond water used in irrigation during dry season in the three sites were $7.37-23.8 \mathrm{mg} / \mathrm{L}$, while the mean concentration in rainy season was $7.17-29.2 \mathrm{mg} / \mathrm{L}$. The mean COD (mg/L) in the tin mine pond water in the sites studied during dry season were in the range of $22.0-36.0 \mathrm{mg} / \mathrm{L}$ and 21.2 $41.6 \pm 2.4 \mathrm{mg} / \mathrm{L}$ in rainy season.

The mean DO of mining pond water sample in dry - and - rainy season of the study sites were obtained in the range of $2.3-2.9 \mathrm{mg} / \mathrm{L}$ and $2.2-2.7 \mathrm{mg} / \mathrm{L}$, respectively. The highest DO was obtained in Jos - South in rainy 
season and lowest at Bokkos in both seasons. The DO in the studied mining pond water reported in this work was lower compared to the DO $6.88 \mathrm{mg} / \mathrm{L}$ and $6.90 \mathrm{mg} / \mathrm{L}$ (Bharose et al., 2013) and (Alghobar and Suresh, 2017), respectively on wastewater used in irrigation.

The mean alkalinity of the tin mining pond water in the study areas were $101-134 \mathrm{mg} / \mathrm{L}$ in dry season and $122-167 \mathrm{mg} / \mathrm{L}$ as the range obtained in rainy season. The highest value was found in Jos - South in both seasons with the lowest obtained in Bokkos and Barkin - Ladi in dry - and - rainy seasons respectively. The value of alkalinity obtained in this work is higher compared to the reported value range $0.8-28.3 \mathrm{mg} / \mathrm{L}$ in Wase mining site Plateau state (Lawal et al., 2014). The mean total hardness of tin mine pond water shows hardness range of 157 - 331 and 139 $258 \mathrm{mg} / \mathrm{L}$ in dry - and - rainy seasons, respectively. The highest value was obtained in Barkin - Ladi in dry season with the lowest in Jos - South during rainy season.

The mean $\mathrm{Cl}^{-}$concentration in dry season of the tin mine pond water were in the range $67.8-90.1 \mathrm{mg} / \mathrm{L}$ and $53.0-61.7 \mathrm{mg} / \mathrm{L}$ in rainy season. All mean values obtained from the tin mine pond water of dry season shows values higher than those obtained during rainy seasons. This may be due to evaporation of mining wastewater and high mining activities during the season. The mean $\mathrm{NO}_{3}{ }^{-}-\mathrm{N}$ concentration in tin mine pond water in the study sites were in the range $7.56-11.2$ and $7.84-8.74 \pm 0.3 \mathrm{mg} / \mathrm{L}$ in dry - and - rainy seasons, respectively. The highest values in this work was obtain in dry - and - rainy seasons both in Barkin - Ladi and lowest in Jos - South. Though these values are lower compared to the findings of $13.08 \mathrm{mg} / \mathrm{L}$ reported in Barkin Ladi (Daniel et al., 2014) and 19.51 mg/L (ElArby and Elbolrdiny, 2006). The mean concentration of $\mathrm{SO}_{4}{ }^{2-}$ in tin mine pond water used for irrigation were in the range $11.2-35.2 \mathrm{mg} / \mathrm{L}$, while the concentration range in rainy was $9.86-34.6 \mathrm{mg} / \mathrm{L}$ with the highest concentration found Jos - South in both seasons. The concentration in $\mathrm{NH}_{4}{ }^{+}$tin mine water pond obtained range from $29.5-35.4$ and $7.82-11.0 \mathrm{mg} / \mathrm{L}$ in dry and rainy seasons, respectively. The highest concentration of ammonia in the tin mine pond water was found in Barkin - Ladi, in both seasons. The values in rainy season were observed to be almost similar during the season.

In dry season, the mean values of phosphate tin mine pond water ranged from $6.30-8.88 \mathrm{mg} / \mathrm{L}$ and 6.52 $10.5 \pm 0.5 \mathrm{mg} / \mathrm{L}$ in rainy season quite higher than dry season, with highest and lowest concentration obtained in Bokkos. The values of phosphate in the tin mine pond water are quite higher than the values used in the irrigation of agricultural fields of Durgapur (Robinson, 2012) and lower compared to reported values in Ishiagu (Nukpezah et al., 2017). The mean value of $\mathrm{F}^{-}$in tin mine pond water in dry and rainy season were in the range $0.0-0.09$ and $0.0-0.21 \mathrm{mg} / \mathrm{L}$, similar concentrations were found in Barkin - Ladi and Jos - South.

There was no much observable seasonal variation in the concentration of $\mathrm{Na}^{+}$in the tin mining pond water during dry - and - rainy seasons with recorded mean values 13.3 - 14.6 and 13.1 - 15.8, respectively. In Bokkos the mean value recorded in the two seasons were $1.13-1.53$ and $3.81-4.63 \mathrm{mg} / \mathrm{L}$ for dry - and - rainy seasons, respectively. The results of the rainy season were almost similar, the highest was recorded in Barkin - Ladi 
Table 2: Mean \pm SD Values of the Physico-chemical Parameters of Mining Pond Water in Plateau, North Central

\begin{tabular}{|c|c|c|c|c|c|c|c|}
\hline \multirow[b]{3}{*}{ Parameters } & \multicolumn{3}{|c|}{ Nigeria } & \multirow{2}{*}{\multicolumn{3}{|c|}{ Rainy }} & \multirow{3}{*}{$\begin{array}{c}\text { FAO/ } \\
\text { WHO } \\
\text { Standards }\end{array}$} \\
\hline & \multicolumn{3}{|c|}{ Dry } & & & & \\
\hline & Bokkos & $\begin{array}{c}\text { Barkin - } \\
\text { Ladi }\end{array}$ & Jos & Bokkos & $\begin{array}{c}\text { Barkin - } \\
\text { Ladi }\end{array}$ & Jos & \\
\hline Turbidity & $22.4 \pm 2.2$ & $27.4 \pm 1.2$ & $18.1 \pm 3.4$ & $15.9 \pm 0.63$ & $16.6 \pm 1.1$ & $18.8 \pm 2.8$ & 5 \\
\hline Temperature & $23.8 \pm 0.56$ & $24.9 \pm 0.49$ & $25.1 \pm 0.32$ & $29.9 \pm 1.2$ & $28.5 \pm 1.3$ & $29.3 \pm 0.73$ & 30 \\
\hline $\mathrm{pH}$ & $6.38 \pm 0.29$ & $6.67 \pm 0.30$ & $6.73 \pm 0.29$ & $6.48 \pm 0.33$ & $6.69 \pm 0.42$ & $6.76 \pm 0.24$ & $6.5-8.5$ \\
\hline $\mathrm{EC}$ & $117 \pm 1.5$ & $109 \pm 1.8$ & $220 \pm 7.3$ & $183 \pm 1.2$ & $128 \pm 2.2$ & $210 \pm 8.5$ & 750 \\
\hline TSS & $640 \pm 10$ & $718 \pm 6.2$ & $520 \pm 17$ & $29.0 \pm 1.5$ & $10.4 \pm 0.65$ & $123 \pm 4.4$ & 100 \\
\hline TDS & $254 \pm 11$ & $288 \pm 7.9$ & $219 \pm 2.4$ & $281 \pm 6.1$ & $414 \pm 5.5$ & $267 \pm 4.5$ & 500 \\
\hline BOD & $7.37 \pm 0.90$ & $9.58 \pm 0.43$ & $23.8 \pm 1.2$ & $7.17 \pm 0.23$ & $9.16 \pm 0.33$ & $29.2 \pm 0.97$ & 2 \\
\hline$C O D$ & $22.0 \pm 1.2$ & $25.3 \pm 0.76$ & $36.0 \pm 0.88$ & $21.2 \pm 1.1$ & $22.0 \pm 0.32$ & $41.6 \pm 2.4$ & 350 \\
\hline DO & $2.9 \pm 1.0$ & $2.2 \pm 1.5$ & $2.3 \pm 0.68$ & $2.2 \pm 0.73$ & $2.7 \pm 0.85$ & $2.2 \pm 0.73$ & 5 \\
\hline TA & $101 \pm 1.3$ & $127 \pm 8.1$ & $134 \pm 4.8$ & $134 \pm 1.3$ & $122 \pm 1.5$ & $167 \pm 1.30$ & 100 \\
\hline $\mathrm{TH}$ & $303 \pm 1.9$ & $331 \pm 0.82$ & $157 \pm 5.8$ & $258 \pm 2.5$ & $254 \pm 4.8$ & $139 \pm 1.7$ & 500 \\
\hline $\mathrm{Cl}^{-}$ & $90.1 \pm 2.3$ & $88.2 \pm 1.6$ & $67.8 \pm 2.2$ & $55.0 \pm 1.4$ & $61.7 \pm 0.91$ & $53.0 \pm 0.92$ & 250 \\
\hline $\mathrm{NO}_{3}{ }^{-}$ & $9.20 \pm 0.77$ & $11.2 \pm 0.35$ & $7.56 \pm 0.43$ & $7.84 \pm 0.38$ & $8.74 \pm 0.31$ & $8.41 \pm 0.39$ & 50 \\
\hline $\mathrm{SO}_{4}{ }^{2-}$ & $11.7 \pm 0.75$ & $7.56 \pm 0.57$ & $35.2 \pm 0.54$ & $11.7 \pm 0.31$ & $9.86 \pm 0.46$ & $34.6 \pm 1.1$ & 500 \\
\hline $\mathrm{TPO}_{4}{ }^{3-}$ & $6.30 \pm 0.86$ & $8.08 \pm 0.32$ & $8.88 \pm 0.93$ & $10.5 \pm 0.46$ & $7.24 \pm 0.29$ & $6.52 \pm 0.78$ & 5 \\
\hline $\mathrm{F}^{-}$ & $0.09 \pm 0.02$ & $0.09 \pm 0.02$ & $0.09 \pm 0.02$ & $0.21 \pm 0.02$ & $0.21 \pm 0.03$ & $0.21 \pm 0.03$ & 1.5 \\
\hline $\mathrm{NH}_{4}{ }^{+}$ & $29.5 \pm 0.57$ & $35.4 \pm 0.68$ & $31.6 \pm 1.2$ & $11.0 \pm 0.57$ & $10.8 \pm 0.27$ & $7.82 \pm 1.3$ & 50 \\
\hline $\mathrm{Na}^{+}$ & $13.6 \pm 0.89$ & $13.3 \pm 1.1$ & $14.6 \pm 1.5$ & $13.1 \pm 1.5$ & $15.8 \pm 1.1$ & $14.5 \pm 1.4$ & 200 \\
\hline $\mathrm{K}^{+}$ & $1.53 \pm 0.1$ & $1.13 \pm 0.03$ & $1.58 \pm 0.12$ & $3.81 \pm 0.2$ & $4.63 \pm 0.27$ & $4.14 \pm 0.07$ & 0.2 \\
\hline
\end{tabular}

All parameters are in $m g / L$ exception of Turbidity (NTU) temperature $\left({ }^{\circ} \mathrm{C}\right) \mathrm{pH}$ and $E C(\mu \mathrm{S} / \mathrm{cm})$ 
Table 3: Pearson's Correlation Coefficient Matrix of Physicochemical Parameters (Mean) of Old Tin Mining Pond Water Bokkos Dry Season

\begin{tabular}{|c|c|c|c|c|c|c|c|c|c|c|c|c|c|c|c|c|c|c|}
\hline & Tub. & Temp & BOD & $\mathrm{COD}$ & DO & $\mathrm{pH}$ & $\mathrm{EC}$ & TSS & TA & TH & $\mathrm{Cl}^{-}$ & $\mathrm{NO}_{3}^{-}$ & $\mathrm{SO}_{4}^{2-}$ & $\mathrm{TPO}_{4}$ & $\mathrm{~F}^{-}$ & $\mathrm{NH}_{4}^{+}$ & $\mathrm{Na}^{+}$ & $\mathrm{K}^{+}$ \\
\hline Tub. & 1.000 & & & & & & & & & & & & & & & & & \\
\hline Temp & 0.503 & 1.000 & & & & & & & & & & & & & & & & \\
\hline$B O D$ & 0.184 & 0.572 & 1.000 & & & & & & & & & & & & & & & \\
\hline $\mathrm{COD}$ & 0.432 & 0.526 & 0.950 & 1.000 & & & & & & & & & & & & & & \\
\hline DO & -0.407 & -0.152 & -0.781 & -0.909 & 1.000 & & & & & & & & & & & & & \\
\hline $\mathrm{pH}$ & 0.018 & 0.836 & 0.769 & 0.590 & -0.214 & 1.000 & & & & & & & & & & & & \\
\hline $\mathrm{EC}$ & -0.462 & 0.445 & 0.013 & -0.263 & 0.614 & 0.621 & 1.000 & & & & & & & & & & & \\
\hline TSS & 0.953 & 0.651 & 0.472 & 0.672 & -0.585 & 0.273 & -0.380 & 1.000 & & & & & & & & & & \\
\hline $\mathrm{TA}$ & 0.343 & -0.047 & -0.811 & -0.691 & 0.669 & -0.499 & 0.018 & 0.069 & 1.000 & & & & & & & & & \\
\hline $\mathrm{TH}$ & 0.977 & 0.583 & 0.087 & 0.305 & -0.220 & 0.065 & -0.290 & 0.909 & 0.477 & 1.000 & & & & & & & & \\
\hline $\mathrm{Cl}^{-}$ & -0.306 & -0.927 & -0.817 & -0.722 & 0.367 & -0.956 & -0.424 & -0.544 & 0.417 & -0.334 & 1.000 & & & & & & & \\
\hline $\mathrm{NO}_{3}^{-}$ & 0.782 & 0.191 & 0.483 & 0.733 & -0.859 & -0.042 & -0.784 & 0.831 & -0.195 & 0.630 & -0.218 & 1.000 & & & & & & \\
\hline $\mathrm{SO}_{4}{ }^{2-}$ & 0.537 & -0.225 & 0.481 & 0.666 & -0.916 & -0.188 & -0.852 & 0.416 & -0.519 & 0.121 & 0.035 & 0.844 & 1.000 & & & & & \\
\hline $\mathrm{TPO}_{4}$ & 0.332 & -0.419 & 0.505 & 0.497 & -0.703 & -0.026 & -0.452 & -0.165 & -0.850 & -0.519 & 0.071 & 0.332 & 0.767 & 1.000 & & & & \\
\hline $\mathrm{F}^{-}$ & 0.412 & 0.757 & 0.958 & 0.946 & -0.724 & 0.805 & 0.037 & 0.668 & -0.610 & 0.348 & -0.908 & 0.551 & 0.388 & 0.264 & 1.000 & & & \\
\hline $\mathrm{NH}_{4}^{+}$ & -0.132 & 0.735 & 0.206 & -0.016 & 0.429 & 0.783 & 0.933 & -0.022 & 0.036 & 0.036 & -0.675 & -0.522 & -0.754 & -0.544 & 0.307 & 1.000 & & \\
\hline $\mathrm{Na}^{+}$ & -0.914 & -0.585 & -0.557 & -0.761 & 0.709 & -0.265 & 0.466 & -0.987 & 0.067 & -0.837 & 0.533 & -0.900 & -0.551 & 0.001 & -0.717 & 0.118 & 1.000 & \\
\hline $\mathrm{K}^{+}$ & 0.172 & -0.605 & 0.056 & 0.265 & -0.643 & -0.595 & -0.945 & 0.137 & -0.259 & -0.026 & 0.475 & 0.654 & 0.896 & 0.696 & -0.062 & -0.966 & -0.259 & 1.000 \\
\hline
\end{tabular}

All parameters are in $\mathrm{mg} / \mathrm{L}$ with the exception of Turbidity $(\mathrm{NTU})$ temperature $\left({ }^{\circ} \mathrm{C}\right), \mathrm{pH}$ and $\mathrm{EC}(\mu \mathrm{S} / \mathrm{cm})$ 
Table 4: Pearson's Correlation Coefficient Matrix of Physicochemical Parameters (Mean) of Old Tin Mining Pond Water Bokkos Rainy Season

\begin{tabular}{|c|c|c|c|c|c|c|c|c|c|c|c|c|c|c|c|c|c|c|}
\hline & Tub. & Temp & BOD & $\mathrm{COD}$ & DO & $\mathrm{pH}$ & $\mathrm{EC}$ & TSS & $\mathrm{TA}$ & $\mathrm{TH}$ & $\mathrm{Cl}^{-}$ & $\mathrm{NO}_{3}^{-}$ & $\mathrm{SO}_{4}^{2-}$ & $\mathrm{TPO}_{4}{ }^{3}$ & $\mathrm{~F}^{-}$ & $\mathrm{NH}_{4}^{+}$ & $\mathrm{Na}^{+}$ & $\mathrm{K}^{+}$ \\
\hline Tub. & 1.000 & & & & & & & & & & & & & & & & & \\
\hline Temp & -0.914 & 1.000 & & & & & & & & & & & & & & & & \\
\hline $\mathrm{BOD}$ & -0.608 & 0.842 & 1.000 & & & & & & & & & & & & & & & \\
\hline $\mathrm{COD}$ & 0.812 & -0.977 & -0.932 & 1.000 & & & & & & & & & & & & & & \\
\hline DO & 0.851 & -0.950 & -0.930 & 0.963 & 1.000 & & & & & & & & & & & & & \\
\hline $\mathrm{pH}$ & 0.224 & -0.190 & -0.467 & 0.246 & 0.477 & 1.000 & & & & & & & & & & & & \\
\hline EC & -0.288 & 0.126 & -0.389 & 0.038 & 0.176 & 0.797 & 1.000 & & & & & & & & & & & \\
\hline TSS & -0.918 & 0.680 & 0.306 & -0.525 & -0.635 & -0.282 & 0.337 & 1.000 & & & & & & & & & & \\
\hline $\mathrm{TA}$ & 0.182 & -0.528 & -0.891 & 0.698 & 0.663 & 0.417 & 0.621 & 0.154 & 1.000 & & & & & & & & & \\
\hline TH & -0.125 & -0.144 & -0.649 & 0.331 & 0.399 & 0.692 & 0.933 & 0.314 & 0.861 & 1.000 & & & & & & & & \\
\hline $\mathrm{Cl}^{-}$ & 0.700 & -0.388 & -0.118 & 0.241 & 0.442 & 0.523 & -0.092 & -0.908 & -0.277 & -0.212 & 1.000 & & & & & & & \\
\hline $\mathrm{NO}_{3}^{-}$ & 0.361 & 0.045 & 0.375 & -0.226 & -0.038 & 0.258 & -0.279 & -0.701 & -0.691 & -0.516 & 0.876 & 1.000 & & & & & & \\
\hline $\mathrm{SO}_{4}{ }^{2-}$ & 0.174 & -0.259 & -0.627 & 0.366 & 0.548 & 0.959 & 0.888 & -0.125 & 0.649 & 0.861 & 0.306 & -0.021 & 1.000 & & & & & \\
\hline $\mathrm{TPO}_{4}{ }^{3}$ & 0.553 & -0.198 & 0.068 & 0.043 & 0.258 & 0.493 & -0.096 & -0.826 & -0.424 & -0.280 & 0.980 & 0.947 & 0.246 & 1.000 & & & & \\
\hline $\mathrm{F}^{-}$ & 0.607 & -0.266 & 0.002 & 0.113 & 0.324 & 0.507 & -0.094 & -0.858 & -0.373 & -0.256 & 0.992 & 0.926 & 0.270 & 0.998 & 1.000 & & & \\
\hline $\mathrm{NH}_{4}^{+}$ & -0.371 & -0.036 & -0.461 & 0.240 & 0.107 & -0.021 & 0.503 & 0.696 & 0.795 & 0.706 & -0.798 & -0.970 & 0.255 & -0.869 & -0.847 & 1.000 & & \\
\hline $\mathrm{Na}^{+}$ & 0.388 & -0.073 & 0.474 & -0.137 & -0.153 & -0.483 & -0.890 & -0.587 & -0.800 & -0.952 & 0.485 & 0.686 & -0.684 & 0.522 & 0.510 & -0.841 & 1.000 & \\
\hline $\mathrm{K}^{+}$ & -0.767 & 0.926 & 0.740 & -0.915 & -0.789 & 0.161 & 0.323 & 0.467 & -0.499 & -0.011 & -0.079 & 0.282 & 0.037 & 0.108 & 0.043 & -0.197 & -0.110 & 1.000 \\
\hline
\end{tabular}

All parameters are in $\mathrm{mg} / \mathrm{L}$ with the exception of Turbidity (NTU) temperature $\left({ }^{\circ} \mathrm{C}\right), \mathrm{pH}$ and $\mathrm{EC}(\mu \mathrm{S} / \mathrm{cm})$ 
Table 5: Pearson's Correlation Coefficient Matrix of Physicochemical Parameters (Mean) of Old Tin Mine Pond Water Barkin- Ladi Dry Season

\begin{tabular}{|c|c|c|c|c|c|c|c|c|c|c|c|c|c|c|c|c|c|c|}
\hline & Tub. & Temp & BOD & COD & DO & $\mathrm{pH}$ & $\mathrm{EC}$ & TSS & $\mathrm{TA}$ & $\mathrm{TH}$ & $\mathrm{Cl}^{-}$ & $\mathrm{NO}_{5}^{-}$ & $\mathrm{SO}_{4}^{2-}$ & $\mathrm{TPO}_{4}{ }^{3-}$ & $\mathrm{F}^{-}$ & $\mathrm{NH}_{4}^{+}$ & $\mathrm{Na}^{+}$ & $\mathrm{K}^{+}$ \\
\hline Tub. & 1.000 & & & & & & & & & & & & & & & & & \\
\hline Temp & 0.431 & 1.000 & & & & & & & & & & & & & & & & \\
\hline BOD & 0.685 & -0.347 & 1.000 & & & & & & & & & & & & & & & \\
\hline COD & -0.383 & 0.263 & -0.723 & 1.000 & & & & & & & & & & & & & & \\
\hline DO & 0.327 & -0.705 & 0.873 & -0.474 & 1.000 & & & & & & & & & & & & & \\
\hline $\mathrm{pH}$ & 0.698 & -0.225 & 0.828 & -0.213 & 0.824 & 1.000 & & & & & & & & & & & & \\
\hline $\mathrm{EC}$ & 0.727 & 0.244 & 0.659 & -0.856 & 0.228 & 0.269 & 1.000 & & & & & & & & & & & \\
\hline TSS & 0.200 & 0.640 & -0.182 & -0.391 & -0.602 & -0.536 & 0.618 & 1.000 & & & & & & & & & & \\
\hline $\mathrm{TA}$ & -0.886 & -0.664 & -0.438 & 0.463 & 0.044 & -0.294 & -0.854 & -0.630 & 1.000 & & & & & & & & & \\
\hline TH & -0.649 & -0.179 & -0.407 & -0.296 & -0.407 & -0.831 & 0.032 & 0.513 & 0.282 & 1.000 & & & & & & & & \\
\hline $\mathrm{Cl}^{-}$ & 0.067 & 0.696 & -0.585 & 0.856 & -0.591 & -0.106 & -0.465 & -0.043 & -0.060 & -0.465 & 1.000 & & & & & & & \\
\hline $\mathrm{NO}_{3}^{-}$ & 0.100 & 0.436 & -0.103 & -0.541 & -0.483 & -0.557 & 0.649 & 0.970 & -0.531 & 0.657 & -0.270 & 1.000 & & & & & & \\
\hline $\mathrm{SO}_{4}{ }^{-2}$ & 0.518 & -0.124 & 0.748 & -0.986 & 0.439 & 0.269 & 0.927 & 0.449 & -0.601 & 0.195 & -0.762 & 0.567 & 1.000 & & & & & \\
\hline $\mathrm{TPO}_{4}^{3}$ & -0.492 & -0.388 & -0.067 & -0.577 & -0.080 & -0.583 & 0.235 & 0.429 & 0.206 & 0.936 & -0.745 & 0.625 & 0.467 & 1.000 & & & & \\
\hline$F^{-}$ & -0.404 & -0.543 & 0.142 & -0.688 & 0.153 & -0.384 & 0.295 & 0.292 & 0.205 & 0.832 & -0.877 & 0.513 & 0.573 & 0.973 & 1.000 & & & \\
\hline $\mathrm{NH}_{4}^{+}$ & -0.664 & 0.055 & -0.824 & 0.945 & -0.494 & -0.415 & -0.952 & -0.393 & 0.692 & -0.012 & 0.667 & -0.479 & -0.982 & -0.294 & -0.414 & 1.000 & & \\
\hline $\mathrm{Na}^{+}$ & 0.892 & 0.437 & 0.639 & -0.669 & 0.183 & 0.402 & 0.950 & 0.557 & -0.962 & -0.235 & -0.198 & 0.516 & 0.782 & -0.070 & -0.017 & -0.859 & 1.000 & \\
\hline $\mathrm{K}^{+}$ & 0.323 & 0.508 & -0.203 & 0.747 & -0.175 & 0.342 & -0.379 & -0.336 & -0.120 & -0.806 & 0.895 & -0.554 & -0.642 & -0.963 & -0.996 & 0.491 & -0.072 & 1.000 \\
\hline
\end{tabular}

All parameters are in $\mathrm{mg} / \mathrm{L}$ with the exception of Turbidity $(\mathrm{NTU})$ temperature $\left({ }^{\circ} \mathrm{C}\right), \mathrm{pH}$ and $\mathrm{EC}(\mu \mathrm{S} / \mathrm{cm})$ 
Table 6: Pearson's Correlation Coefficient Matrix of Physicochemical Parameters (Mean) of Old Tin Mine Pond Water Barkin- Ladi Rainy Season

\begin{tabular}{|c|c|c|c|c|c|c|c|c|c|c|c|c|c|c|c|c|c|c|}
\hline & Tub. & Temp & BOD & $\mathrm{COD}$ & DO & $\mathrm{Ph}$ & $\mathrm{EC}$ & TSS & TA & $\mathrm{TH}$ & $\mathrm{Cl}^{-}$ & $\mathrm{NO}_{3}^{-}$ & $\mathrm{SO}_{4}{ }^{2-}$ & $\mathrm{TPO}_{4}{ }^{3}$ & $\mathrm{~F}$ & $\mathrm{NH}_{4}^{+}$ & $\mathrm{Na}^{+}$ & $\mathrm{K}^{+}$ \\
\hline Tub. & 1.000 & & & & & & & & & & & & & & & & & \\
\hline Temp & 0.040 & 1.000 & & & & & & & & & & & & & & & & \\
\hline$B O D$ & -0.173 & 0.254 & 1.000 & & & & & & & & & & & & & & & \\
\hline $\mathrm{COD}$ & 0.939 & -0.010 & -0.499 & 1.000 & & & & & & & & & & & & & & \\
\hline $\mathrm{DO}$ & 0.416 & 0.925 & 0.191 & 0.339 & 1.000 & & & & & & & & & & & & & \\
\hline $\mathrm{pH}$ & 0.050 & 0.990 & 0.384 & -0.047 & 0.923 & 1.000 & & & & & & & & & & & & \\
\hline $\mathrm{EC}$ & -0.628 & 0.577 & 0.734 & -0.786 & 0.299 & 0.633 & 1.000 & & & & & & & & & & & \\
\hline TSS & 0.919 & -0.357 & -0.264 & 0.882 & 0.025 & -0.343 & -0.815 & 1.000 & & & & & & & & & & \\
\hline TA & -0.574 & -0.198 & 0.813 & -0.803 & -0.377 & -0.089 & 0.649 & -0.094 & 1.000 & & & & & & & & & \\
\hline TH & -0.658 & 0.726 & 0.352 & -0.667 & 0.411 & 0.717 & 0.887 & -0.901 & 0.280 & 1.000 & & & & & & & & \\
\hline $\mathrm{Cl}^{-}$ & 0.917 & 0.247 & 0.218 & 0.735 & 0.582 & 0.302 & -0.282 & 0.759 & -0.292 & -0.430 & 1.000 & & & & & & & \\
\hline $\mathrm{NO}_{3}^{-}$ & 0.924 & 0.207 & -0.440 & 0.976 & 0.531 & 0.167 & -0.646 & 0.783 & -0.833 & -0.494 & 0.768 & 1.000 & & & & & & \\
\hline $\mathrm{TPO}_{4}{ }^{3}$ & -0.642 & -0.268 & -0.643 & -0.343 & -0.507 & -0.375 & -0.102 & -0.493 & -0.171 & 0.208 & -0.886 & -0.386 & -0.317 & 1.000 & & & & \\
\hline $\mathrm{F}^{-}$ & -0.412 & -0.719 & 0.438 & -0.552 & -0.795 & -0.634 & 0.122 & -0.103 & 0.824 & -0.233 & -0.330 & -0.698 & -0.259 & 0.013 & 1.000 & & & \\
\hline $\mathrm{NH}_{4}^{+}$ & -0.422 & 0.785 & 0.683 & -0.577 & 0.565 & 0.832 & 0.956 & -0.704 & 0.439 & 0.899 & -0.074 & -0.397 & 0.989 & -0.231 & -0.146 & 1.000 & & \\
\hline $\mathrm{Na}^{+}$ & -0.482 & 0.293 & -0.612 & -0.188 & 0.062 & 0.170 & 0.087 & -0.565 & -0.434 & 0.517 & -0.653 & -0.113 & 0.083 & 0.829 & -0.496 & 0.109 & 1.000 & \\
\hline $\mathrm{K}^{+}$ & -0.991 & -0.171 & 0.172 & -0.936 & -0.532 & -0.175 & 0.561 & -0.859 & 0.621 & 0.553 & -0.924 & -0.951 & 0.187 & 0.641 & 0.522 & 0.327 & 0.406 & 1.000 \\
\hline
\end{tabular}

All parameters are in $m g / L$ with the exception of Turbidity (NTU) temperature $\left({ }^{\circ} \mathrm{C}\right), \mathrm{pH}$ and $\mathrm{EC}(\mu \mathrm{S} / \mathrm{cm})$ 
Table 7: Pearson's Correlation Coefficient Matrix of Physicochemical Parameters (Mean) of Old Tin Mine Pond Water Dry Season Jos- South

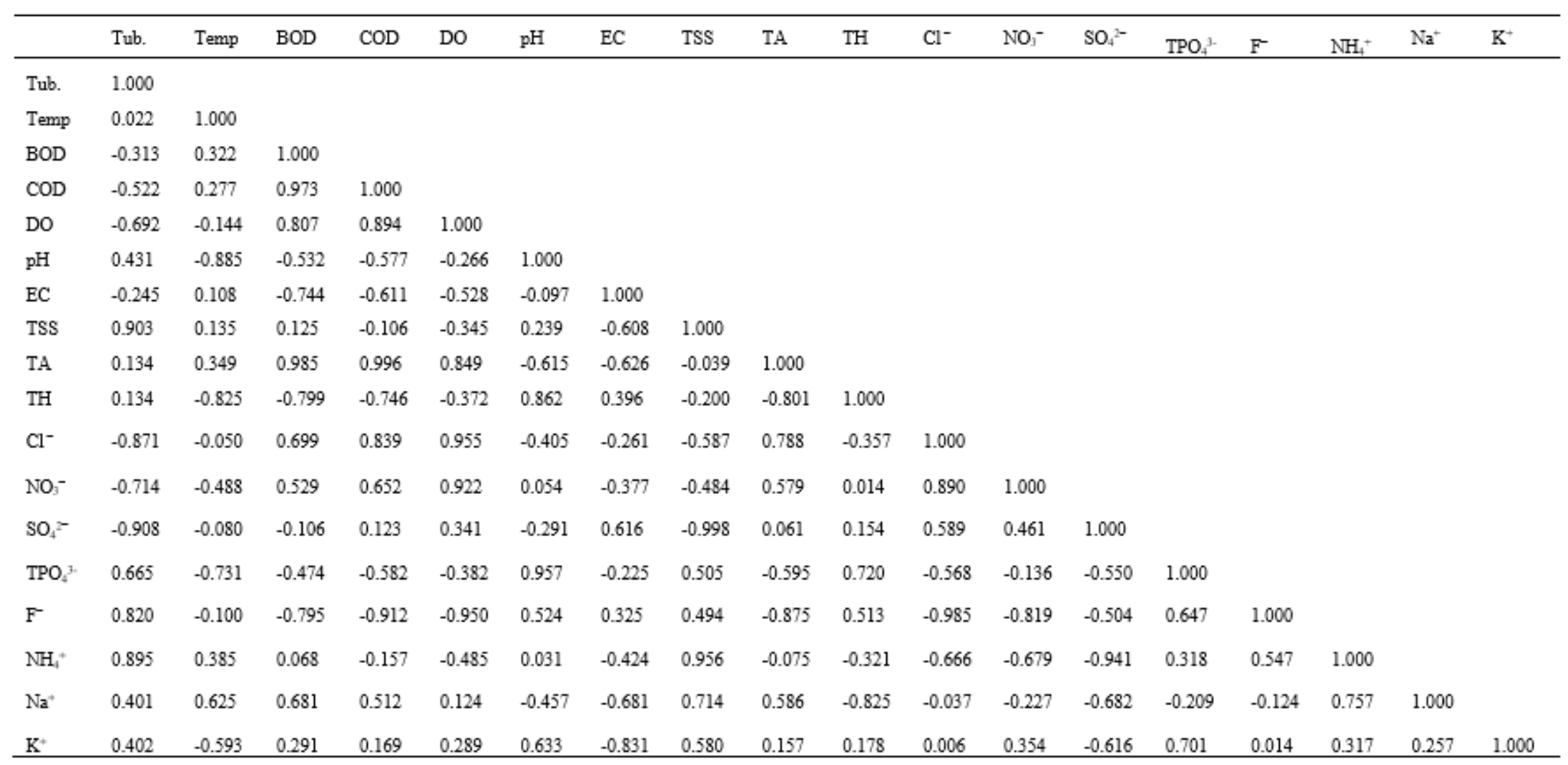

All parameters are in $\mathrm{mg} / \mathrm{L}$ with the exception of Turbidity (NTU) temperature $\left({ }^{\circ} \mathrm{C}\right), \mathrm{pH}$ and $\mathrm{EC}(\mu \mathrm{S} / \mathrm{cm})$ 
Table 8: Pearson's Correlation Coefficient Matrix of Physicochemical Parameters (Mean) of Old Tin Mine Pond Water Rainy Season

\begin{tabular}{|c|c|c|c|c|c|c|c|c|c|c|c|c|c|c|c|c|c|c|}
\hline & Tub. & Temp & BOD & COD & DO & $\mathrm{Ph}$ & $\mathrm{EC}$ & TSS & $\mathrm{TA}$ & $\mathrm{TH}$ & $\mathrm{Cl}^{-}$ & $\mathrm{NO}_{3}^{-}$ & $\mathrm{SO}_{4}{ }^{2-}$ & $\mathrm{TPO}^{3-}$ & $\mathrm{F}^{-}$ & $\mathrm{NH}_{i}^{+}$ & $\mathrm{Na}^{+}$ & $\mathrm{K}^{+}$ \\
\hline Tub. & 1.000 & & & & & & & & & & & & & & & & & \\
\hline Temp & 0.345 & 1.000 & & & & & & & & & & & & & & & & \\
\hline BOD & -0.867 & -0.380 & 1.000 & & & & & & & & & & & & & & & \\
\hline$C O D$ & -0.550 & 0.479 & 0.629 & 1.000 & & & & & & & & & & & & & & \\
\hline DO & -0.538 & 0.505 & 0.202 & 0.641 & 1.000 & & & & & & & & & & & & & \\
\hline $\mathrm{pH}$ & 0.821 & 0.599 & -0.515 & -0.011 & -0.384 & 1.000 & & & & & & & & & & & & \\
\hline $\mathrm{EC}$ & -0.735 & 0.339 & 0.705 & 0.962 & 0.757 & -0.276 & 1.000 & & & & & & & & & & & \\
\hline TSS & 0.211 & -0.478 & -0.516 & -0.875 & -0.225 & -0.384 & -0.720 & 1.000 & & & & & & & & & & \\
\hline TA & 0.284 & -0.692 & -0.399 & -0.956 & -0.584 & -0.261 & -0.855 & 0.913 & 1.000 & & & & & & & & & \\
\hline TH & -0.601 & -0.050 & 0.890 & 0.790 & 0.126 & -0.077 & 0.742 & -0.836 & -0.670 & 1.000 & & & & & & & & \\
\hline $\mathrm{Cl}^{-}$ & -0.921 & -0.150 & 0.953 & 0.784 & 0.486 & -0.538 & 0.876 & -0.569 & -0.571 & 0.853 & 1.000 & & & & & & & \\
\hline $\mathrm{NO}_{3}^{-}$ & -0.080 & 0.887 & 0.088 & 0.829 & 0.675 & 0.358 & 0.726 & -0.752 & -0.939 & 0.374 & 0.320 & 1.000 & & & & & & \\
\hline $\mathrm{SO}_{4}^{2-}$ & -0.345 & 0.313 & -0.142 & 0.160 & 0.860 & -0.506 & 0.339 & 0.297 & -0.109 & -0.356 & 0.117 & 0.305 & 1.000 & & & & & \\
\hline $\mathrm{TPO}_{4}^{5-}$ & -0.986 & -0.356 & 0.938 & 0.603 & 0.450 & -0.738 & 0.755 & -0.329 & -0.343 & 0.720 & 0.963 & 0.098 & 0.195 & 1.000 & & & & \\
\hline $\mathrm{F}^{-}$ & -0.123 & 0.385 & -0.365 & 0.007 & 0.763 & -0.355 & 0.157 & 0.397 & -0.013 & -0.540 & -0.110 & 0.269 & 0.973 & -0.034 & 1.000 & & & \\
\hline $\mathrm{NH}_{+}^{+}$ & 0.721 & -0.382 & -0.485 & -0.802 & -0.952 & 0.444 & -0.912 & 0.415 & 0.694 & -0.414 & -0.726 & -0.678 & -0.695 & -0.672 & -0.542 & 1.000 & & \\
\hline $\mathrm{Na}^{+}$ & 0.533 & 0.794 & -0.784 & -0.067 & 0.414 & 0.406 & -0.117 & 0.155 & -0.146 & -0.635 & -0.562 & 0.477 & 0.558 & -0.627 & 0.708 & -0.143 & 1.000 & \\
\hline $\mathrm{K}^{*}$ & -0.158 & -0.850 & -0.038 & -0.738 & -0.331 & -0.648 & -0.545 & 0.860 & 0.901 & -0.443 & -0.180 & -0.919 & 0.080 & 0.086 & 0.081 & 0.371 & -0.360 & 1.000 \\
\hline
\end{tabular}

All parameters are in $\mathrm{mg} / \mathrm{L}$ with the exception of Turbidity (NTU) temperature $\left.{ }^{\rho} \mathrm{C}\right), \mathrm{pH}$ and $\mathrm{EC}(\mu \mathrm{S} / \mathrm{cm})$ 


\section{DISCUSSION}

\section{TURBIDITY}

All the samples from the studied mined ponds recorded mean values that were above the FAO, (1985) standards for irrigation water. However, higher values may indicate the presence of particulate matter such as clay/silt, decomposed organic matter and other forms of pollutants that reduce the transparency of the water contributed by illegal mining currently taking place in the area by local miners, as such; treatment is necessary to get desired result (Murhekar, 2011). Activities such as; the use of excavators, earth moving equipment, shovels and pick axe in the excavation of tin ores could enhance the dissolution and or washing of silt into the mining ponds, these are prone in Barkin - Ladi compared to other study areas because of the location of the pond which is very close to mechanical workshops and block industries. Thus, impurities from runoff into the various open ponds contributes to the elevated level of turbidity (Mafuyai et al., 2019b). The higher levels of turbidity reported along the mining ponds could largely be due to the activities of small-scale miners as reported (Yidana et al., 2012). Irrigating vegetables with turbid water could affect the quality of the vegetables produced, since bacteria and viruses could attach and migrate to the vegetables through solid particles in the water (Jeong et al., 2016). Also, high turbidity levels in irrigation water affects the aesthetic quality of the vegetables produced as reported by some farmers from the study area (Mafuyai et al., 2019b).

\section{TEMPERATURE}

The high temperature $25.1{ }^{\circ} \mathrm{C}$ and $29.3{ }^{\circ} \mathrm{C}$ in dry and rainy seasons obtained in Jos South may be unconnected to high solar radiation in rainy seasons, absence of vegetative cover around the ponds and heating from industries and households around the ponds. The temperatures obtained during the rainy season were higher than those of dry season as recorded in this study. All values are within the FAO/WHO, (2007) standards. However, the values of temperature reported in this work are in agreement with studies on the Seasonal physicochemical characteristics of Nagani/Wubang mined pond water in Langtang North Local Government Area of Plateau state (Gongden and Lohdip 2015).

\section{pH}

The $\mathrm{pH}$ is positively correlated with BOD and COD, and negatively correlated with DO in both dry - and - rainy season at $(\mathrm{p}<0.05)$. The slight acidity of the mining pond water could be due to the addition of excess mineral from the geologic soil from the mining area activities on Land use/Land covering Bukuru, Plateau State (Jiya and Musa, 2012). This observation may be due to the presence of algae and other aquatic plants on the surface of the reservoir. Algal respiration leads to the release of carbon dioxide which reacts with the water to produce carbonic acid, which result in an increased acidity (Yidana et al., 2012). Similarly, microbial utilization of dissolved oxygen releases carbon dioxide which reacts with water to produce carbonic acid resulting in a lower $\mathrm{pH}$. The greatest hazard associated with an abnormal $\mathrm{pH}$ in irrigation water is its impact on the equipment used for irrigation where it is not correctly calibrated with the required buffer (Jeong et al., 2016). Furthermore, crop foliage is damaged when it gets wet by water with abnormal $\mathrm{pH}$, this could result in reduction in yield and also depreciation of the quality of marketable material (crops). The slight acidity of the mine pond water can affect crops when directly in contact with the leave and on the one hand, by a release of exchangeable cations during a process of an organic material mineralization brought by wastewater 
(Hussain et al., 2010; Kiziloglu et al., 2008). The pH obtained in this work agrees with the literatures reported by Anim-Gyampo et al. 2012 and Bao et al. 2014.

\section{ELECTRICAL CONDUCTIVITY (EC)}

The mean values of mining pond water of the two seasons did not show much elevated EC in the years, but the values were higher in Jos - South during both dry and rainy season than the other sites ( 220 and $\left.210 \mu \mathrm{Scm}^{-1}\right)$, respectively. Several studies showed significant variation in the electrical conductivity compared to the values obtained in this work (Kangpe et al. 2014; Osuocha et al. 2016; Mahmood and Malik, 2014). The different EC recorded by the authors might be due the parent rock type which showed lower EC values in Nagani/Wubang dam water in north central Nigeria (Gongden and Lohdip, 2015). Higher EC values in the water was due to the illegal mining taking place around the abandoned ponds supported by the study of Artisanal and small-scale miners in solid minerals industry (Davou and Dung - Gwom, 2008). Also, the higher EC in the rainy season may be due washing of ashes from bush burning that empty water into the ponds. However, the values obtained in this work were far lower compared with $723 \mu \mathrm{S} \mathrm{cm}$

${ }^{1}$ reported in Haipang, Plateau State (Daniel et al., 2014). From the EC value it is quite clear that both sources of irrigation water will not pose any soil salinity problem in the future and the EC values are within the safe limit prescribed standard by FAO/WHO (2007). The values of EC obtained from the sites corroborated with report of Kampani River in Wase, Plateau State (Lawal et al., 2014).

\section{TOTAL SUSPENDED SOLIDS (TSS)}

The mean of the suspended solids results indicates that there is a high variation of TSS values in the two seasons as they differ greatly. However, the TSS values observed during the rainy season were within the limit of FAO/WHO (2007) standard for irrigation water, while the values obtained in dry season were above the recommended values. This is because mining by artisanal miners is high during the dry season which produces a lot soil debris (Davou and Dung-Gwom, 2008). The TSS values of mining pond water were higher in comparison with some of the ponds water reported in Haipang (Daniel et al., 2014). In most of the municipal wastewater the TSS values ranges from 10 to 20 $\mathrm{mg} / \mathrm{L}$ and values below $100 \mathrm{mg} / \mathrm{L}$ pose no restriction to irrigation use. The higher values obtained in this work can pose threat to irrigation pending on the type of crops grown.

\section{TOTAL DISSOLVED SOLIDS (TDS)}

The mean TDS values for the tin mining pond water in the various studies sites were in the range of $219-288 \mathrm{mg} / \mathrm{L}$ in dry season, and $267-414 \mathrm{mg} / \mathrm{L}$ in rainy season. The values indicate that the water TDS is influenced by seasonal variations, this may be due to higher rate of evaporation in dry season and less influx and runoff water during dry and rainy season. All the TDS values, obtained from this studyare well within the safe limit of prescribed irrigation water quality standards (FAO, 1985). The classification of the water on the basis of TDS indicates that the mining water is good for irrigation when other required parameters satisfy the requirements. 


\section{BIOCHEMICAL OXYGEN DEMAND (BOD)}

Biochemical oxygen demand (BOD) represents the quantity of oxygen required by bacteria and other microorganisms to degrade and transformation of organic matter present in wastewater under aerobic conditions. From result obtained it is observed that the highest BOD was found ranged from $7.37-29.3 \mathrm{mg} / \mathrm{L}$ in the three study in both seasons with the lowest in Bokkos. These values obtained for BOD are higher than the prescribed standard $2 \mathrm{mg}-\mathrm{O}_{2} / \mathrm{L}$ for irrigation water. The high level of BOD in the mining pond water also indicated the presence of excessive number of bacteria in the water, which consumed the dissolved oxygen (WHO/FAO, 2007; FEPA, 1991).

\section{CHEMICAL OXYGEN DEMAND (COD)}

The chemical oxygen demand (COD) is a measure of the oxygen equivalent to that portion of organic matter present in the wastewater sample that is susceptible to oxidation by oxidizing agents (i.e., potassium dichromate). It is a quick estimation of organic loading in wastewater. The higher COD value observed in Jos - South in rainy season, this might be due to the anthropogenic activities and dilution with runoff discharges from sewage water. But the COD values of mine pond water are below the safe limit as prescribed by WHO, (1993), though lower compared to $964 \mathrm{mg} / \mathrm{L}$ reported on wastewater used in irrigation (Alghobar and Suresh, 2017).

\section{DISSOLVED OXYGEN (DO)}

DO is an important water quality parameter for most chemical and biological processes in water bodies and is essential for all aquatic life. As BOD was very much higher in the mining pond water, the dissolved oxygen (DO) was very much lower than the prescribed irrigation water quality standard. This indicates that the water may be toxic for aquatic life in that area and it might cause many diseases in crops. The values DO show a positive correlation with the BOD in dry seasons. This indicates that the water needs treatment to support aquatic life (Bamniya et al., 2010).

\section{TOTAL ALKALINITY}

Alkalinity is a measure of the acid buffering capacity of water. It is the sum of the amounts of bicarbonates $\left(\mathrm{HCO}_{3}{ }^{-}\right)$, carbonates $\left(\mathrm{CO}_{3}{ }^{2-}\right)$ and hydroxide $\left(\mathrm{OH}^{-}\right)$in water. The high value in Jos - South in both seasons may be attributed to drains and washings from industries and households while in the ponds there are no houses close this may be due to lack of diluting water (Mafuyai et al., 2019b). The mean values other sites showed almost similar alkalinity with in the mining pond water in during the seasons. The alkalinities of irrigation water obtained are within the safe limit of FAO, (1985) and there is no need to calculate the residual sodium carbonate (RSC) and permeability index (PI) of such irrigation water.

\section{TOTAL HARDNESS (TH)}

The presence of multivalent cations, most notably calcium and magnesium ions, is referred to as water hardness. Both sources of water have considerable amount of hardness, which is due to addition of ions either by leaching from rocks in case of groundwater or washing of rocks and from mining exploration in case of mining pond water. The values of hardness in irrigation water obtained in this study follow similar trend with the values reported in Kampani mine River, Nigeria (Lawal et al., 2014) and $317.3 \mathrm{mg} / \mathrm{L}$ in Haipang, Barkin- Ladi (Daniel et al., 2014). The high values in 
tin mining pond water in this study is thus, lower compared to the prescribed $500 \mathrm{mg} / \mathrm{L}$ irrigation water standard value (FAO, 1985).

\section{CHLORIDE (CL $\left.{ }^{-}\right)$}

The mean values $\mathrm{Cl}^{-}$recorded in this work are higher ranging from $11.3-43.4 \mathrm{mg} / \mathrm{L}$ in both sampled sites of the studies, but higher than the reported value $12.19 \mathrm{mg} / \mathrm{L}$ of Kampani mine dam in Wase, Plateau, Nigeria (Lawal et al., 2014) and however, lower compared to the result $98.7 \mathrm{mg} / \mathrm{L}$ obtained at Haipang Barkin-Ladi mining pond (Daniel et al., 2014) and $124.4 \mathrm{mg} / \mathrm{L}$ reported in Ishiagu, Ebonyi State (Osuocha et al., 2016). The chloride concentrations of irrigation water sources are within the prescribed limit (FAO, 1985). All the mining pond water sources in terms chloride quality are good and can be regarded for used in irrigation along other satisfactory parameters without any restriction.

\section{NITRATE-NITROGEN $\left(\mathrm{NO}_{3}{ }^{-}-\mathrm{N}\right)$}

All the concentrations of nitrate recorded during the entire study period fell within the FAO permissible limit of 10 $\mathrm{mg} / \mathrm{L}$ for irrigation water use, exception of the mining pond water in Barkin Ladi $(11.2 \mathrm{mg} / \mathrm{L})$ in dry season. High concentration of nitrate in irrigation water can also cause excessive vegetative growth, poor quality fruiting and delay maturity in crops (Gongden and Lohdip, 2015). The presence of nitrate in the water may be due to surface-runs or leaching from the soils of surrounding farms which indicates the use of nitrogen fertilizer by farmers. This was confirmed by the farmers that they use fertilizer in the areas for crop production. Furthermore, indiscriminate defaecation around water banks and by miners/farmers might also influence the concentration of nitrogen in the water which may lead to the high BOD in the mining pond water (Mafuyai et al., 2019b).

\section{SULPHATE $\left(\mathrm{SO}_{4}{ }^{2-}\right)$}

The high sulphate in Jos - South may be due weathering of rocks or leaching from rocks that contain calcium sulphate, magnesium sulphate and/or sodium sulphate (Okoffo, 2016). Other possible sources could be anthropogenic activities, most likely, industrial, farming and prolonged illegal mining at the areas. All the mining pond water sources in the study areas are far lower than the prescribed standards limit (FAO, 1985). The result of this findings agrees with values ranged 3.30 - $73.9 \mathrm{mg} / \mathrm{L}$ reported (Bharose et al., 2013), but was however, lower compared with $280-300 \mathrm{mg} / \mathrm{L}$ reported in Mista Ali Bassa, Plateau State (Kangpe et al., 2014), these might have been due the topography and the mine pond far from water loading or the use of sulphate fertilizers close to the ponds (UNEP, 2005).

\section{TOTAL PHOSPHATE $\left(\mathrm{PO}_{4}{ }^{3-}\right)$}

The phosphate is a normal component in surface water which is derived from natural processes but its quantity increases with input of effluents from domestic and industrial sources. Agricultural sector also contributes phosphate residue through runoff water. Irrigation with phosphate enriched water leads to increase the fertility of the soil. The values obtained in this work are far above the permissible limit of $2.0 \mathrm{mg} / \mathrm{L}$ for irrigation water (FAO, 1985). Water enriched with phosphorus could enhance the rapid growth of algae and other aquatic plants. The presence of phosphates in the water at all the sites might be as a result of the use of organophosphate pesticides and phosphate fertilizers by farmers that leached into the ponds (Davou and Dung-Gwom, 2008). 


\section{FLUORIDE ( $\left.\mathbf{F}^{-}\right)$}

The geogenic sources are responsible for the fluoride $(\mathrm{F}-)$ in the irrigation water. The values of mine pond water in dry season were very closer though, in rainy season fluoride values are higher, this might be due to high evaporation and washing of dumps and tailings into mining ponds. The mean value obtained in this study is lower compared to the prescribed safe limit of $1.5 \mathrm{mg} / \mathrm{L}$ (WHO, 2008). The higher due to high evaporation and diminishing flow of the mining pond water channel.

\section{AMMONIUM $\left(\mathrm{NH}_{4}{ }^{+}\right)$}

Comparing the results $\mathrm{NH}_{4}{ }^{-}$obtained with previous studies in the same area by Henry the changes (increases) in $\mathrm{NH}_{4}{ }^{+}$ concentrations in the tin mine pond water, probably indicate that the $\mathrm{NH}_{4}{ }^{+}$is derived from an anthropogenic source and can also be attributed to contamination since some ponds were abandoned and refuse are dumped into some of this ponds by water run-off (Mafuyai et al., 2019b).

\section{$\operatorname{SODIUM}\left(\mathbf{N A}^{+}\right)$}

The concentration of $\mathrm{Na}^{+}$obtained in this study is higher than the value of $1.45-5.26 \mathrm{mg} / \mathrm{L}$ (Hussain et al., 2010) and lower compared with literature value $48.0 \mathrm{mg} / \mathrm{L}$ reported in Mysore City Karnataka (Low et al., 2016) and the mean value of $34.2 \mathrm{mg} / \mathrm{L}$ from Okpauku River in Nigeria (Akpan-Idiok et al., 2012). The causes of high $\mathrm{Na}^{+}$content in mining pond water during rainy season may be due to the input from burnt ashes washed and emptied into the ponds (Mafuyai et al., 2019b). The concentrations of sodium in the mining pond water for the entire study period were far below the FAO permissible limits of $920 \mathrm{mg} / \mathrm{L}$ for irrigation water (FAO, 1985).

\section{POTASSIUM $\left(\mathbf{K}^{+}\right)$}

The mean concentration of potassium in mining pond water does not showed variation with seasons and notably it is also found that the potassium level is remarkably lower dry season are lower compared to FAO/WHO (2007) limits of $2 \mathrm{mg} / \mathrm{L}$ irrigation water standard, while those obtained during rainy seasons has higher $\mathrm{K}^{+}$concentrations than the FAO, recommended limit. The concentration of $\mathrm{K}^{+}$in tin mining pond water shows a positive correlation with $\mathrm{Cl}^{-}$and TSS in dry season and negative correlation EC and COD. The high concentration may be due to natural occurrence in water of $\mathrm{K}^{+}$through weathering of rocks and anthropogenic sources.

\section{CORRELATION ANALYSIS}

Correlation of physico-chemical parameters in Bokkos dry and rainy seasons are respectively in (Table 3 and 4), turbidity shows positive correlation with $\mathrm{TSS}, \mathrm{NO}_{3}{ }^{-}$and Hardness in dry season while rainy season turbidity was positively correlated with COD, DO, Cl- and negatively correlated with TSS (Table 4). BOD was positively correlated with COD in dry and negatively with DO in rainy season, while in dry season COD was negatively correlated DO and positively with $\mathrm{DO}$ in rainy season. The $\mathrm{pH}$ of the tin mining pond was positively correlated with the EC in both seasons, thus the EC positively correlated with $\mathrm{SO}_{4}{ }^{2-}, \mathrm{NH}_{4}{ }^{+}$in both dry and rainy seasons. $\mathrm{SO}_{4}{ }^{2-}$ and $\mathrm{NO}_{3}{ }^{-}$were positively correlated with $\mathrm{PO}_{4}^{3-}$ and $\mathrm{SO}_{4}{ }^{2-}$ respectively, while the TSS was observed to correlate positively with $\mathrm{NO}_{3}{ }^{-}$ . The total alkalinity was positively correlated with $\mathrm{Na}+$ and Hardness in both dry and rainy seasons in Bokkos. 
In Barkin-Ladi (Table 5 and 6), turbidity correlated positively with EC and pH In dry season, and negatively with $\mathrm{COD}, \mathrm{NO}_{3}{ }^{-}$, while BOD correlated positively with DO. The COD in both rainy and dry season correlated positively with $\mathrm{Cl}^{-}$. The EC correlated positively TSS, $\mathrm{SO}_{4}{ }^{2-}$ in both two seasons. The tin mining pond water TSS shows positive correlation $\mathrm{NO}_{3}{ }^{-} \mathrm{Cl}^{-}$in both dry and rainy season. The total hardness was positively correlated with $\mathrm{TPO}_{4}{ }^{3-}$ in dry season and $\mathrm{SO}_{4}{ }^{2-}, \mathrm{NH}_{4}+$ in rainy seasons, while $\mathrm{PO}_{4}{ }^{3-}$ was positively correlated $\mathrm{F}^{-}$and $\mathrm{SO}_{4}{ }^{2-}, \mathrm{NH}_{4}{ }^{+}$in both seasons see (Table 6).

In Jos-South (Table 7 and 8), the turbidity correlated positively with TSS and $\mathrm{pH}$ in dry and rainy seasons, while the BOD correlated positively with COD, DO and total hardness in dry season. The COD correlated positively with DO, total alkalinity $\mathrm{Cl}^{-}$in dry season and $\mathrm{EC}$ rainy season. The $\mathrm{DO}$ correlated positively with $\mathrm{NO}_{3}{ }^{-}$and $\mathrm{EC}$ in dry and rainy season. The $\mathrm{pH}$ was positively correlated $\mathrm{PO}_{4}{ }^{3-} \mathrm{Cl}^{-}$, while the TSS was positively correlated with $\mathrm{NH}_{4}{ }^{+}$, $\mathrm{Na}^{+}$and negatively correlated with $\mathrm{SO}_{4}^{2-}$ in dry season and rainy positively correlated with alkalinity. The $\mathrm{Cl}^{-}$was positively correlated with $\mathrm{NO}_{3}{ }^{-}$and negatively correlated with $\mathrm{F}^{-}$in dry season, while in rainy season $\mathrm{NH}_{4}{ }^{+}$was positively correlated with $\mathrm{Na}^{+}$. Looking at the correlation coefficients of the physico -chemical parameters is a clear indication of the contribution of these ionic components to the overall mineralization of the water. The positive correlation exhibited among the parameters examined is a clear indication of a common source of ionic contribution.

The mean differences of the two irrigation water sources are calculated with the help of student t-test. The mean difference of control parameters in dry- and -rainy season showed significant $(\mathrm{p}<0.05)$ differences $(\mathrm{t}=3.182)$ between turbidity, temperature, total hardness, total alkalinity, total dissolved solids, dissolved oxygen biological oxygen demand, chemical oxygen demand, ammonia, chloride and fluoride, except $\mathrm{pH}, \mathrm{Na}+$, at both seasons in Bokkos and $\mathrm{NO}_{3}{ }^{-}$in dry season, while $\mathrm{pH}, \mathrm{EC}$ and $\mathrm{pH}, \mathrm{NO}_{3}{ }^{-}, \mathrm{Na}^{+}$in Barkin - Ladi and Jos - South, respectively. Although values of $\mathrm{Na}^{+}, \mathrm{K}^{+}$and TSS, $\mathrm{TPO}_{4}$ - in dry - and- seasons, respectively were not significant, it can be inferred that tin mining pond water and seasonal changes have significant contribution over the variability of the said parameters.

\section{CONCLUSION}

Evaluation of seasonal physico-chemical data from the study area have provided information on the quality of tin mine pond water, sources of pollution and their suitability for consumption and irrigation purposes. Some of the physicochemical parameters of all sampled water fell within FAO/WHO guideline values for irrigation water with the exception of turbidity, dissolved oxygen, total alkalinity, biological oxygen demand, total phosphate and potassium which were higher than recommended limits in both dry and rainy seasons. The total suspended solids were also higher in dry season in mine pond water. The positive correlation exhibited among the parameters examined is a clear indication of a similar source of pollution contribution. This study is very significance as it has revealed that some of physicochemical qualities of mining pond water used for irrigation are abnormal and may likely be detrimental to irrigated crops and humans. Therefore, the mining pond water used for irrigation should be closely monitored by the relevant authorities of government to ensure that the over usage of the does not cause toxicity to the irrigated crops. 


\section{DECLARATION}

I on behalf of the coauthors of the work, hereby declare that this manuscript has not been published in any scientific journal or submitted for review and publication.

\section{ACKNOWLEDGEMENT}

The authors would like to acknowledge Prof. I. S. Eneji, of Department Chemistry University of Agriculture Makurdi, Benue State, Bala Ajik, Department Science Laboratory Technology University of Jos, Plateau State for drawing the maps of the study site and my Wife Mrs. Victoria Godwin Mafuyai of University of Jos Health Services, for their various contributions in bringing this article to completion for publication, thank you and God bless. 


\section{REFERENCE}

Akpan-Idiok, A.U., Ibrahim, A. and Udo, I.A. (2012). Water quality assessment of riv for drinking and irrigation uses in Yala, Cross River State, Nigeria. Journal of Environmental Sciences, 6(6):210-221.

Alghobar, M.A. and Suresha, S. (2017). Evaluation of Metal Accumulation in Soil and Tomatoes irrigated with Sewage water from Mysore City Karnataka, India. Journal of Saudi Society of Agricultural Science 16: 49 -59 .

Anim-Gyampo, M., Apori, N. and Kumi. M. (2012). Assessment of heavy metals in wastewater irrigated lettuce in Ghana: The case of Tamale Municipality. Journal of Sustainable Development, 5(11): 93 - 102.

AOAC. (2000) (Association of Official and Analytical Chemistry). Official methods of analysis (by Dr. William Horwitz) 17th ed. Gaithersburg, M.D, USA.

APHA. (1998). Standard methods for the examination of water and wastewater (20th ed.), Washington, DC.

Balamurugan, G. (1991). Tin mining and sediment supply in Peninsular Malaysia with special reference to the Kelang River basin. Environmentalist 11:281-291.

Bamniya, B.R., Kapasya, V. and Kapoor, C.S. (2010). Physiological and biochemical studies on the effect of waste water on selected crop plants. Biological Forum - An International Journal of Biological Sciences , 2(2): 13.

Bao, Z., Wu, W., Liu, H., Chen, H. and Yin, S. (2014). Impact of long-term irrigation with sewage on heavy metals in soils, crops and groundwater - a case study in Beijing. Polish Journal of Environmental Studies, 23(2):309318.

Bharose, R., Lal, S.B., Singh, S.K. and Srivastava, P.K. (2013). Heavy metals pollution in soil-water-vegetation continuum irrigated with ground water and untreated sewage. Bulletin of Environmental and Scientific Research, 2(1):1-8.

Bixio, B., Thoeye, C., De Koning, J., Joksimovic, D., Savic, D., Wintgens, T. and Melin, T. (2006) Wastewater reuse in Europe. Desalination 187, 89-101.

Daniel, V.N., Chundusu, E.S. and Chup, J.A. (2014). Heavy Metals Accumulation in Agricultural Soils Irrigated with Tin - Mine Water in B/Ladi, Plateau State, Nigeria. International Journal of ～Engineering \& Technology, 14(4): $69-74$.

Davou, D.D. and Dung-Gwom, J.Y. (2008). The Problems and Challenges and Prospects of Artisanal and Small Scale Miners in the Solid Minerals Industry. Paper presented at the Second ASESEDA NUC National Workshop on Solid Minerals Development in Nigeria, University of Jos 2', - 5' June 2008.

El-Arby, A.M. and Elbordiny, M.M. (2006). Impact of reused wastewater for irrigation on availability of heavy metals in sandy soils and their uptake by plants. Journal of Applied Sciences Research, 2(2):106-111.

FAO, (1985). Water Quality for Agriculture. Paper No. 29 (Rev.1) UNESCO, Publication, Rome.

FEPA, (1991) Proposed National Water Quality Standards. Federal Environmental Protection Agency, Nigeria. 
Gongden, J. J. and Lohdip, Y.N. (2015). Seasonal variation of the surface water quality of two dams in Plateau State, North Central Nigeria. Transactions on Ecology and the Environment, 196: 291-298. Water Resources Management VIII 291.

Gupta, S., Satpati, S., Nayek, S. and Garai, D. (2010). Effect of wastewater irrigation on vegetables in relation to bioaccumulation of heavy metals and biochemical changes. Environmental Monitoring Assessment, 165:169-177.

Gupta, S., Nayek, S., Saha, R.N. and Satpati S. (2008). Assessment of heavy metal accumulation in macrophyte, agricultural soil, and crop plants adjacent to discharge zone of sponge iron factory. Environmental Geology, 55: 731-739.

Gurel, M., Iskender, G., Ovez, S., Arslan-Alaton, I., Tanik, A. and Orhon, D. (2007). A global overview of treated wastewater guidelines and standards for agricultural reuse. Fresenius Environmental Bulletin, 16(6): 590595 .

Hussain, G., Alquwaizany, A. and Al-Zarah, A. (2010). Guidelines for irrigation water quality and water management in the Kingdom of Saudi Arabia: An Overview. Journal of Applied Science, 10: 79-96.

Jeong, H. Kim, H. and Jang, T. (2016). Irrigation Water Quality Standards for Indirect Wastewater Reuse in Agriculture: A Contribution toward Sustainable Wastewater Reuse in South Korea. Water, 8(5): 169.

Jiya, S. and Musa, H.D. (2012). Impact of derived Tin Mining Activities on Land use/Land covering Bukuru, Plateau State, Nigeria. Journal of sustainable Development, 5(5):913-963.

Kazi, T.G., Arain, M. B., Jamali, M.K., Jalbani, N., Afridi, H.I., Sarfraz, R.A., Baig, J.A. and Shah, A.Q. (2009).

Assessment of water quality of polluted lake using multivariate statistical techniques: a case study. Ecotoxicology and Environmental. Safety, 72: 301-309.

Kangpe, N.S., Egga, E.S. and Mafuyai, G.M. (2014). Physico-Chemical and Microbial Assessment of Some Well Water from Mista-Ali Town, Bassa LGA, Plateau State, Nigeria. Asian Review of Environmental and Earth Sciences, 1(2): 39-42.

Khatri, N. and Tyagi, S. (2015). Influences of natural and anthropogenic factors on surface and groundwater quality in rural and urban areas. Front Life Science., 8(1): 23-39.

Kiziloglu, F. M., Turan, M., Sahin, U., Kuslu, Y., \& Dursun, A. (2008). Effects of untreated and treated wastewater irrigation on some chemical properties of cauliflower (Brassica olerecea L. var. botrytis) and red cabbage (Brassica olerecea L. var. rubra) grown on calcareous soil in Turkey. Agricultural water management, 95(6), 716-724.

Koki, I.B., Low, K.H., Juahir, H., Azid, A. and Zain S.M. (2017). Assessment of water quality of man-made lakes in Klang Valley (Malaysia): the impact of mining. Desalin Water Treatment. 74: 125-136.

Lawal, R.A., Lohdip, Y.N. and Egila, J.N. (2014). Water Quality Assessment of Kampani River, Plateau State, Nigeria. Asian Review of Environmental and Earth Sciences, 1(2): 30-34.

Low, K.H., Koki, I.B., Juahir,H., Behkami, S., Ikram, R., Mohammed, H.A. and Zain, S.M. (2016). Evaluation of water quality variation in lakes, rivers, and ex-mining ponds in Malaysia (review). Desaline. Water Treatment, 57, 58, 2821528239. 
Mafuyai, G. M., Eneji, I. S., Sha'Ato R. and Nnamonu,L. A. (2019a). Heavy Metal Concentration in Soil Irrigated with Ex- Tin Mining Ponds Water, Bokkos L.G.A Plateau State, Nigeria. African Journal of Environment and Natural Science Research, 2(3):13-28.

Mafuyai, G. M., Eneji, I. S., Sha'Ato, R. and Nnamonu, L. A. (2019b). Heavy Metals in Soil and Vegetables Irrigated with Ex- Tin Mining Ponds Water in Barkin - Ladi Local Government Area Plateau State, Nigeria. Agriculture and Food Sciences Research, 6(2): 211-220.

Mafuyai, G.M. (2020). Effect of Irrigation Water from Tin Mining Ponds on Mineral Composition of Plants and Soil in Bokkos, Barkin - Ladi and Jos South Local Government Areas, Plateau State. Thesis submitted to the School of Postgraduate Studies, Federal University of Agriculture Makurdi in partial fulfiment of the requirement for the award of Doctor of Philosophy in Environmental Chemistry Unpublished Thesis.

Mahmood, A. and Malik, R.N. (2014). Human health risk assessment of heavy metals via consumption of contaminated vegetables collected from different irrigation sources in Lahore. Pakistan. Arabian Journal of Chemistry, 7: 91-99.

Manas, P., Castro, E. and Heras, J.D.L. (2009). Irrigation with treated wastewater: Effects on soil, lettuce (Lactuca sativa L.) crop and dynamics of microorganisms. Journal of Environmental Science and Health Part A, 44:1261-1273.

Muhammad, A.A., Mohd, J.M. and Ismail, B.Y. (2010). Study of Water Quality and Heavy Metals in Soil and Water of Ex-Mining Area Bestari Jaya, Peninsular Malaysia. International Journal of Basic and Applied Sciences, 10(3): $7-27$.

Murhekar, G.H. (2011). Assessment of physicochemical status of ground water samples in Akot city. Research Journal of Chemical Sciences, 1(4): 117-124.

NPC. (2006). National population commission of Nigeria. Census Report of the Federal Republic of Nigeria, Abuja.

Nukpezah, D., Abdul-Rahman, F. and Koranteng, S.S. (2017). The Impact of Small Scale Mining on Irrigation Water Quality in Asante Akim Central Municipality of Ghana. West African Journal of Applied Ecology, 25(2):4967.

Okoffo, D.E. (2016). Assessment of pesticide residue in water, soil and cocoa beans in the dorma west district of Ghana. University of Ghana Journal, 2:123-134.

Osuocha, K.U., Chukwu, E.C., Ugbogu, E.A., Atasie, O.C. and Ogbonna, C.E.(2016). Effects of Quarry Mining activities on the Nutritional Composition of Edible Vegetables in Ishiagu, Ebonyi State, Nigeria. Journal of Experimental Biology and Agricultural Sciences, 4(5):467-474.

Patterson, G.(1986). Lake Pidong “A Preliminary Survey of a Volcanic Crater Lake”. Jos Plateau Environmental Resources Development Programme. (J.P.E.R.D.P.) Department of Geography, University of Durham. Interim Report No. 10, Durham, England.

Robinson, R. (2012). pH and the Environment. Research Journal of Chemical Sciences, 3(1): 95-103.

Rolli, N.M. (2014). Heavy metal accumulation in vegetables irrigated with sewage and its impacton health. Research Journal of Recent Sciences, 3: (IVC-2014), 8184. 
Samuel, M. W., Grace, M.A. and Charles, E.U. (2015). Abandoned Mine, Potential Home for the People: A CaseStudy of Jos Plateau Tin-Mining Region. Journal of Civil Engineering and Architecture, 9: 429 - 445.

Singh, A., Sharma, R.K., Agrawal, M. and Marshall, F. (2009). Effects of wastewater irrigation on physicochemical properties of soil and availability of heavy metals in soil and vegetables. Communications in Soil Science and Plant Analysis, 40:3469-3490.

UNEP. (2005). Water and Wastewater Reuse. Environmentally Sound Approach for Sustainable Urban Water Management.

WHO/FAO, (2007). Joint FAO/WHO Food Standard Programme Codex Alimentarius Commission 13th Session. Report of the Thirty Eight Session of the Codex Committee on Food.

WHO, (1993) World Health Organisation; Evaluation of Certain Food Additives and Contaminants. In: Forty-First Report of the Joint FAO/WHO Expert Committee on Food Additives. WHO, Geneva, Switzerland, WHO Technical Series, 83.

WHO. (2008). World Health Organization: Guidelines for Drinking Water Quality: Supporting Documentation to Guidelines. $3^{\text {rd }}$ edition. 2, 552.

Yidana, S.M., Banoeng-Yakubo, B. and Sakyi, P.A. (2012). Identifying key processes in the hydrochemistry of a basin through the combined use of factor and regression models. Journal of Earth System Science, 121(2): 491507. 